Marquette University

e-Publications@Marquette

9-15-2007

\title{
Reactivity of $\left[\operatorname{Re}_{2}(\mathrm{CO})_{8}(\mathrm{MeCN})_{2}\right]$ with Thiazoles: Hydrido Bridged Dirhenium Compounds Bearing Thiazoles in Different Coordination Modes
}

\author{
Shariff E. Kabir \\ Jahangirnagar University \\ Faruque Ahmed \\ Jahangirnagar University \\ Anamika Das \\ Jahangirnagar University \\ Mohammad R. Hassan \\ Jahangirnagar University \\ Daniel T. Haworth \\ Marquette University
}

See next page for additional authors

Follow this and additional works at: https://epublications.marquette.edu/chem_fac

Part of the Chemistry Commons

\section{Recommended Citation}

Kabir, Shariff E.; Ahmed, Faruque; Das, Anamika; Hassan, Mohammad R.; Haworth, Daniel T.; Lindeman, Sergey V.; Hossain, G. M. Golzar; Siddiquee, Tasneem; and Bennett, Dennis W., "Reactivity of $\left[\operatorname{Re}_{2}(\mathrm{CO})_{8}(\mathrm{MeCN})_{2}\right]$ with Thiazoles: Hydrido Bridged Dirhenium Compounds Bearing Thiazoles in Different Coordination Modes" (2007). Chemistry Faculty Research and Publications. 627.

https://epublications.marquette.edu/chem_fac/627 


\section{Authors}

Shariff E. Kabir, Faruque Ahmed, Anamika Das, Mohammad R. Hassan, Daniel T. Haworth, Sergey V. Lindeman, G. M. Golzar Hossain, Tasneem Siddiquee, and Dennis W. Bennett 


\section{Marquette University \\ e-Publications@Marquette}

\section{Chemistry Faculty Research and Publications/College of Arts and Sciences}

This paper is NOT THE PUBLISHED VERSION; but the author's final, peer-reviewed manuscript. The published version may be accessed by following the link in the citation below.

Journal of Organometallic Chemistry, Vol. 692, No. 20 (September 15, 2007): 4337-4345. DOI. This article is $\odot$ Elsevier and permission has been granted for this version to appear in $\underline{\mathrm{e}-}$ Publications@Marquette. Elsevier does not grant permission for this article to be further copied/distributed or hosted elsewhere without the express permission from Elsevier.

REACTIVITY OF $\left[\mathrm{RE}_{2}(\mathrm{CO})_{8}(\mathrm{MECN})_{2}\right]$ WITH THIAZOLES: HYDRIDO BRIDGED DIRHENIUM COMPOUNDS BEARING THIAZOLES IN DIFFERENT COORDINATION MODES

Shariff E. Kabir

Department of Chemistry, Jahangirnagar University, Savar, Dhaka-1342, Bangladesh

Faruque Ahmed

Department of Chemistry, Jahangirnagar University, Savar, Dhaka-1342, Bangladesh

Anamika Das

Department of Chemistry, Jahangirnagar University, Savar, Dhaka-1342, Bangladesh

Mohammad R. Hassan

Department of Chemistry, Jahangirnagar University, Savar, Dhaka-1342, Bangladesh

Daniel T. Haworth

Department of Chemistry, Marquette University, Milwaukee, WI

Sergey V. Lindeman

Department of Chemistry, Marquette University, Milwaukee, WI

G. M. Golzar Hossain

Department of Chemistry, Dhaka University, Dhaka-1000, Bangladesh

Tasneem A. Siddiquee

Department of Chemistry, University of Wisconsin-Milwaukee, WI

Dennis W. Bennett

Department of Chemistry, University of Wisconsin-Milwaukee, WI 


\section{ABSTRACT}

Reactions of the labile compound $\left[\mathrm{Re}_{2}(\mathrm{CO})_{8}(\mathrm{MeCN})_{2}\right]$ with thiazole and 4-methylthiazole in refluxing benzene afforded the new compounds $\left[\mathrm{Re}_{2}(\mathrm{CO}){ }_{7}\left\{\mu-2,3-\eta^{2}-\mathrm{C}_{3} \mathrm{H}(\mathrm{R}) \mathrm{NS}\right\}\left\{\eta^{1}-\mathrm{NC}_{3} \mathrm{H}_{2}(4-\right.\right.$ $\mathrm{R}) \mathrm{S}\}(\mu-\mathrm{H})]\left(\mathbf{1}, \mathrm{R}=\mathrm{H} ; \mathbf{2}, \mathrm{R}=\mathrm{CH}_{3}\right),\left[\mathrm{Re}_{2}(\mathrm{CO})_{6}\left\{\mu-2,3-\eta^{2}-\mathrm{C}_{3} \mathrm{H}(\mathrm{R}) \mathrm{NS}\right\}\left\{\eta^{1}-\mathrm{NC}_{3} \mathrm{H}_{2}(4-\mathrm{R}) \mathrm{S}\right\}_{2}(\mu-\mathrm{H})\right](\mathbf{3}$, $\left.\mathrm{R}=\mathrm{H} ; 4, \mathrm{R}=\mathrm{CH}_{3}\right)$ and fac- $\left[\mathrm{Re}(\mathrm{CO})_{3}(\mathrm{Cl})\left\{\eta^{1}-\mathrm{NC}_{3} \mathrm{H}_{2}(4-\mathrm{R}) \mathrm{S}\right\}_{2}\right]\left(5, \mathrm{R}=\mathrm{H} ; \mathbf{6}, \mathrm{R}=\mathrm{CH}_{3}\right)$.

Compounds 1 and 2 contain two rhenium atoms, one bridging thiazolide ligand, coordinated through the $\mathrm{C}(2)$ and $\mathrm{N}$ atoms and a $\eta^{1}$-thiazole ligand coordinated through the nitrogen atom to the same $\mathrm{Re}$ as the thiazolide nitrogen. Compounds 3 and 4 contain a $\operatorname{Re}_{2}(\mathrm{CO})_{6} \mathrm{group}$ with one bridging thiazolide ligand coordinated through the $\mathrm{C}(2)$ and $\mathrm{N}$ atoms and two Ncoordinated $\eta^{1}$-thiazole ligands, each coordinated to one Re atom. A hydride ligand, formed by oxidative-addition of $\mathrm{C}(2)-\mathrm{H}$ bond of the ligand, bridges $\mathrm{Re}-\mathrm{Re}$ bond opposite the thiazolide ligand in compounds $\mathbf{1 - 4}$. Compound $\mathbf{5}$ contains a single rhenium atom with three carbonyl ligands, two $\mathrm{N}$-coordinated $\eta^{1}$-thiazole ligands and a terminal $\mathrm{Cl}$ ligand. Treatment of both 1 and 2 with 5 equiv. of thiazole and 4-methylthiazole in the presence of $\mathrm{Me}_{3} \mathrm{NO}$ in refluxing benzene afforded 3 and $\mathbf{4}$, respectively. Further activation of the coordinated $\eta^{1-}$ thiazole ligands in 1-4 is, however, unsuccessful and results only nonspecific decomposition. The single-crystal XRD structures of $\mathbf{1 - 5}$ are reported.

\section{GRAPHICAL ABSTRACT}

$\left[\mathrm{Re}_{2}(\mathrm{CO})_{8}(\mathrm{MeCN})_{2}\right]$ reacted with thiazole and 4-methylthiazole, respectively, by oxidative addition and $\eta^{1-c o o r d i n a t i o n}$ to furnish a series of new compounds $\left[\operatorname{Re}_{2}(C O)_{7}\left\{\mu-2,3-\eta^{2-}\right.\right.$ $\left.\left.\mathrm{C}_{3} \mathrm{H}(\mathrm{R}) \mathrm{NS}\right\}\left\{\eta^{1}-\mathrm{NC}_{3} \mathrm{H}_{2}(4-\mathrm{R}) \mathrm{S}\right\}(\mu-\mathrm{H})\right]\left(1, \mathrm{R}=\mathrm{H} ; 2, \mathrm{R}=\mathrm{CH}_{3}\right),\left[\mathrm{Re}_{2}(\mathrm{CO})_{6}\left\{\mu-2,3-\eta^{2}-\mathrm{C}_{3} \mathrm{H}(\mathrm{R}) \mathrm{NS}\right\}\left\{\eta^{1-}\right.\right.$ $\left.\mathrm{NC}_{3} \mathrm{H}_{2}(4-\mathrm{R}) \mathrm{S}_{2}(\mu-\mathrm{H})\right]\left(\mathbf{3}, \mathrm{R}=\mathrm{H} ; \mathbf{4}, \mathrm{R}=\mathrm{CH}_{3}\right)$ and fac- $\left[\mathrm{Re}(\mathrm{CO})_{3}(\mathrm{Cl})\left\{\eta^{1} \mathrm{NC}_{3} \mathrm{H}_{2}(4-\mathrm{R}) \mathrm{S}\right\}_{2}\right](\mathbf{5}, \mathrm{R}=\mathrm{H} ; \mathbf{6}$, $\left.\mathrm{R}=\mathrm{CH}_{3}\right)$.

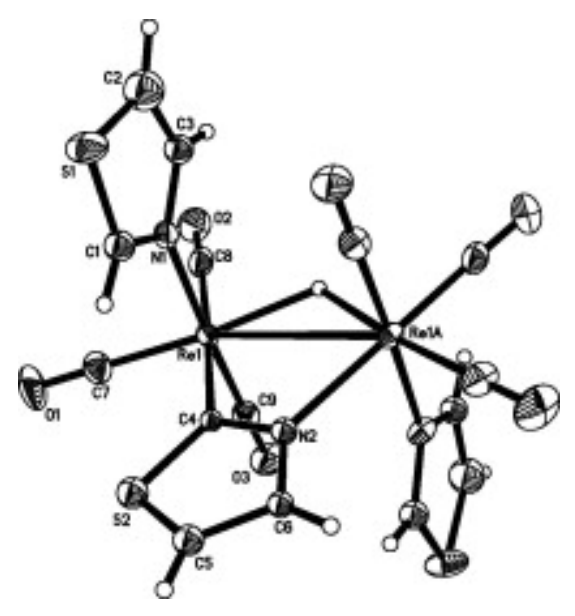

\section{KEYWORDS}

Rhenium carbonyl, Oxidative addition, Thiazolide, N-coordinated thiazole, X-ray structures 


\section{INTRODUCTION}

Aromatic nitrogen and sulfur heterocycles represent an important class of ligands in organometallic chemistry. ${ }^{1}$ Such ligands offer new possibilities for the preparation of bi- and polynuclear complexes with potential application in catalysis. Binuclear complexes bridged by multidentate ligands have been the subjects of considerable amount of work in the last two decades. ${ }^{2}$ Rhenium complexes of the general formula $\left[\operatorname{Re}_{2}(\mu-Y)(\mathrm{CO})_{8}(\mu-\mathrm{H})\right]\left(\mathrm{Y}=\mathrm{PR}_{2} .{ }^{3} \mathrm{Cl}, \mathrm{I},{ }^{4} \eta^{2-}\right.$ pyridyl, ${ }^{5} \eta^{2}-\mathrm{C} \equiv \mathrm{CR},{ }^{6} \eta^{2-} \mathrm{C}=\mathrm{CRR}^{\prime},{ }^{7} \mathrm{C}(\mathrm{R}) \mathrm{O} .{ }^{8} \mathrm{SR}^{9}$ ) are well known in organometallic chemistry. Currently, there is considerable interest in the reactivity of $\mathrm{N}$ - and $\mathrm{S}$-containing aromatic heterocyclic molecules with transition metal carbonyl compounds because the presence of more than one type of donor atoms in such ligands can introduce novel reactivity and frequently stabilizes the metal cluster frame work by serving as bridging or chelating ligands. ${ }^{10}$ Over the last years, we investigated the oxidative-addition reactions of a series of $\mathrm{N}$ - and $\mathrm{S}$ containing aromatic heterocyclic ligands such as benzothiazole, ${ }^{11}$ thiomorpholine,${ }^{12}$ thiazolidine, ${ }^{12} 4$-methylthiazole ${ }^{13}$ and thiazole ${ }^{14,15}$ with ruthenium and osmium carbonyl clusters and observed a remarkable influence on the type of the product obtained depending on the metal carbonyl compounds, the heterocyclic ligands as well as the reaction conditions. For example, thiomorpholine, $\mathrm{C}_{4} \mathrm{H}_{9} \mathrm{NS}$, reacts with $\left[\mathrm{Ru}_{3}(\mathrm{CO})_{12}\right]$ at $66{ }^{\circ} \mathrm{C}$ to give $\left[\mathrm{Ru}_{3}\left(\mu-\eta^{2-}\right.\right.$ $\left.\left.\mathrm{SCH}_{2} \mathrm{CH}_{2} \mathrm{NH}_{2}\right)(\mathrm{CO})_{9}\right]$ by a ring opening reaction of the ligand followed by elimination of a $\mathrm{C}_{2}$ fragment whereas under identical conditions thiazolidine, $\mathrm{C}_{3} \mathrm{H}_{7} \mathrm{NS}$, forms the dinuclear compound $\left[\mathrm{Ru}_{2}\left(\mu-\eta^{3}-\mathrm{SCH}_{2} \mathrm{CH}_{2} \mathrm{NHCH}_{2}\right)(\mathrm{CO})_{6}\right]$ by a ring opening cleavage of the ligand as well as rapture of metal-metal bonds (Scheme 1 ). ${ }^{12}$ We extended our research work to 4methylthiazole and thiazole and observed that the former reacts with $\left[\mathrm{Os}_{3}(\mathrm{CO})_{10}(\mathrm{MeCN})_{2}\right]$ at ambient temperature to give $\left[\mathrm{Os}_{3}(\mathrm{CO})_{10}\left(\mu-2,3-\eta^{2}-\mathrm{C}=\mathrm{NCMe}=\mathrm{CHS}-\right)(\mu-\mathrm{H})\right]$ by activation of the $\mathrm{C}(2)-\mathrm{H}$ bond and coordination of the thiazolide ligand through the nitrogen and $\mathrm{C}(2)$ atoms ${ }^{13}$ while the latter under identical conditions gives two isomeric compounds $\left[\mathrm{Os}_{3}(\mathrm{CO})_{10}\left(\mu-2,3-\eta^{2}-\mathrm{C}\right.\right.$ $=\mathrm{NCH}=\mathrm{CHS}-(\mu-\mathrm{H})]$ and $\left[\mathrm{Os}_{3}(\mathrm{CO})_{10}\left(\mu-3,4-\eta^{2}-\mathrm{HC}=\mathrm{NC}=\mathrm{CHS}-\right)(\mu-\mathrm{H})\right]$ by activation of $\mathrm{C}(2)-$ $\mathrm{H}$ and $\mathrm{C}(4)-\mathrm{H}$ bonds, respectively (Scheme 2). ${ }^{14}$ On the other hand, $\left[\mathrm{Ru}_{3}(\mathrm{CO})_{12}\right]$ reacts with excess thiazole in the presence of sodium benzophenone ketyl to afford the 1:2 compound $\left[\mathrm{Ru}_{3}(\mathrm{CO})_{8}\left(\mu-\eta^{2}-\mathrm{NSC}_{3} \mathrm{H}_{2}\right)_{2}(\mu-\mathrm{H})_{2}\right]$ and the unusual thiazole ring opening product $\left[\mathrm{Ru}_{5}(\mathrm{CO})_{13}\left(\mu-\eta^{2-}\right.\right.$ $\left.\left.\mathrm{NSC}_{3} \mathrm{H}_{2}\right)\left(\eta^{1}-\mathrm{NSC}_{3} \mathrm{H}_{3}\right)\left(\mu_{5}-\eta^{5}-\mathrm{NSC}_{3} \mathrm{H}_{2}\right)(\mu-\mathrm{H})_{2}\right]$, containing three thiazole derived ligands in different coordination modes. ${ }^{15}$ 


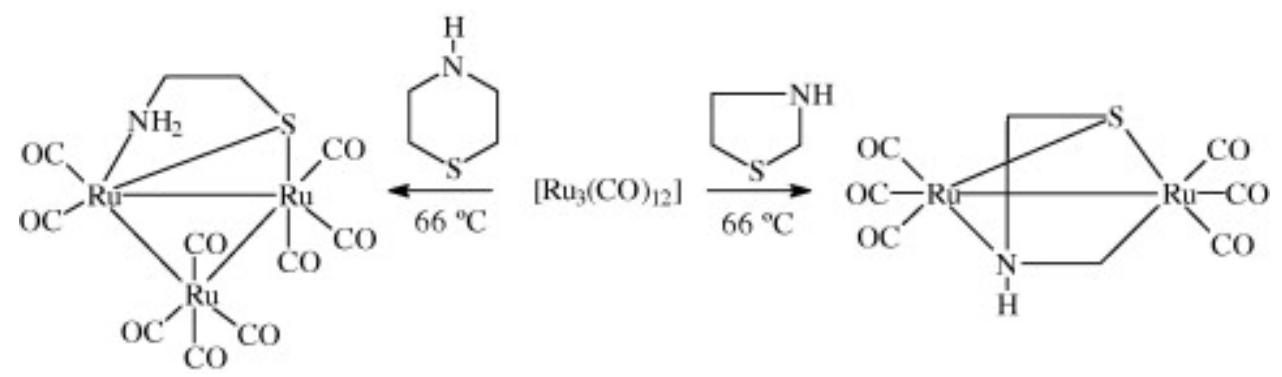

Scheme 1.
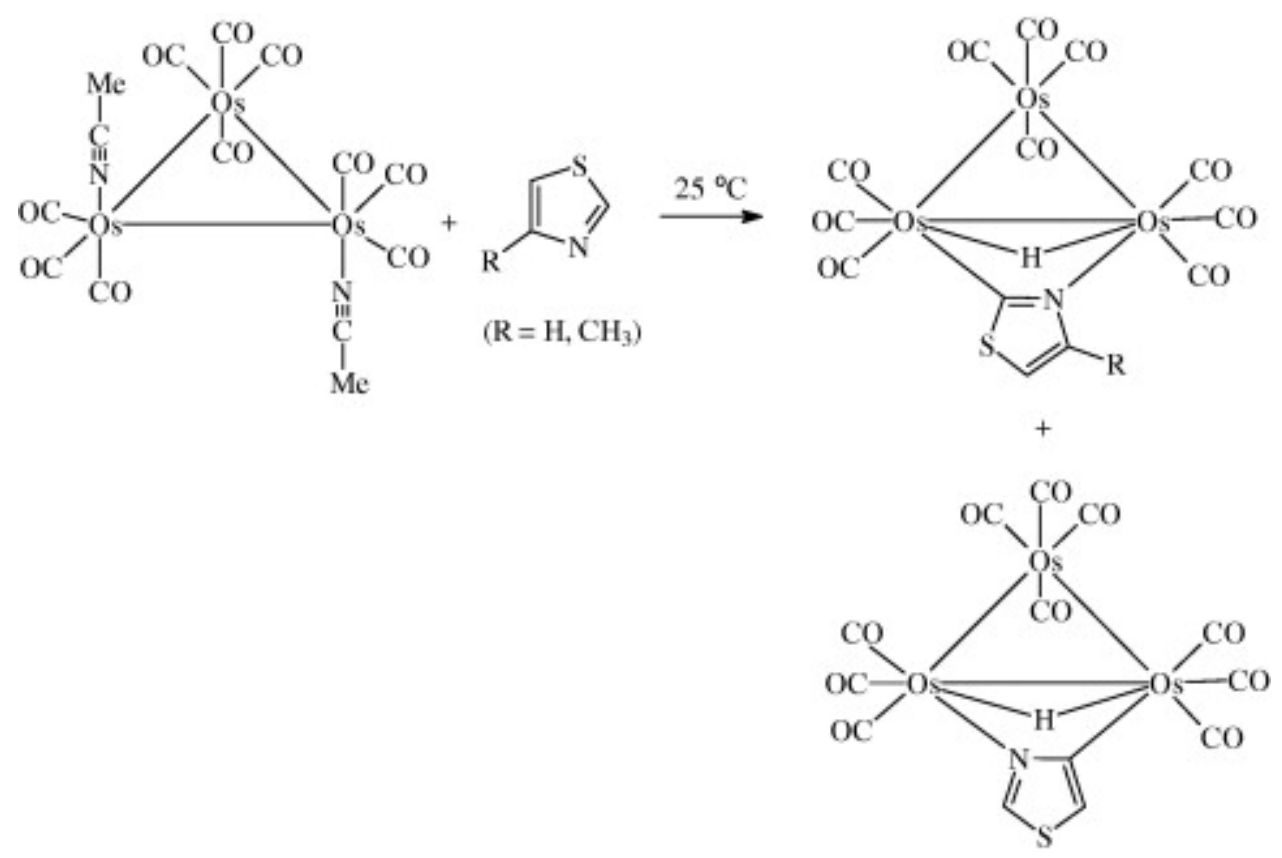

Scheme 2.

Wishing to extend our S- and N-containing heterocyclic ligand studies with group 7 metals, we have explored the reactivity of thiazole and 4-methylthiazole with $\left[\mathrm{Re}_{2}(\mathrm{CO})_{8}(\mathrm{MeCN})_{2}\right]$ and obtained dinuclear complexes $\left[\mathrm{Re}_{2}(\mathrm{CO})_{7}\left\{\mu-2,3-\eta^{2}-\mathrm{C}_{3} \mathrm{H}(4-\mathrm{R}) \mathrm{NS}\right\}\left\{\eta^{1-}-\mathrm{NC}_{3} \mathrm{H}_{2}-(4-\mathrm{R}) \mathrm{S}\right\}(\mu-\mathrm{H})\right](\mathbf{1}$, $\left.\mathrm{R}=\mathrm{H} ; 2, \mathrm{R}=\mathrm{CH}_{3}\right)$, containing two thiazole ligands and $\left[\mathrm{Re}_{2}(\mathrm{CO})_{6}\left\{\mu-2,3-\eta^{2}-\mathrm{C}_{3} \mathrm{H}(\mathrm{R}) \mathrm{NS}\right\}\left\{\eta^{1-}\right.\right.$ $\left.\mathrm{NC}_{3} \mathrm{H}_{2}(4-\mathrm{R}) \mathrm{S}_{2}(\mu-\mathrm{H})\right]\left(3, \mathrm{R}=\mathrm{H} ; 4, \mathrm{R}=\mathrm{CH}_{3}\right)$, containing three thiazole ligands. We have found that in case of $\mathrm{C}-\mathrm{H}$ oxidative addition, coordination to the metal atoms occurs through the nitrogen and $\mathrm{C}(2)$ carbon atoms while in case of $\eta^{1}$-coordinated ligand, the coordination is exclusively through the nitrogen atom of the ring.

\section{EXPERIMENTAL}

General comments. All the reactions were performed under a nitrogen atmosphere using standard Schlenk techniques. Solvents were dried and distilled prior to use by standard 
methods. Thiazole and 4-methylthiazole were purchased from Aldrich and used as received. $\mathrm{Me}_{3} \mathrm{NO} \cdot 2 \mathrm{H}_{2} \mathrm{O}$ was purchased from Lancaster and water from it was removed using a DeanStark apparatus using benzene as a solvent. The starting compound $\left[\operatorname{Re}_{2}(\mathrm{CO})_{8}(\mathrm{MeCN})_{2}\right]$ was prepared according to the published procedure. ${ }^{16}$ Infrared spectra were recorded on a Shimadzu FTIR 8101 spectrophotometer. ${ }^{1} \mathrm{H}$ NMR spectra were recorded on Bruker DPX 400 spectrometer. Elemental analysis was performed by BCSIR Laboratories, Dhaka. Fast atom bombardment mass spectra were obtained on a JEOL SX-102 spectrometer using 3nitrobenzyl alcohol as matrix and CsI as calibrant.

\subsection{REACTION OF $\left[\operatorname{RE}_{2}(\mathrm{CO})_{8}(\mathrm{MECN})_{2}\right]$ WITH THIAZOLE}

$\left[\operatorname{Re}_{2}(\mathrm{CO})_{8}(\mathrm{MeCN})_{2}\right](150 \mathrm{mg}, 0.22 \mathrm{mmol})$, thiazole $(94 \mathrm{mg}, 1.10 \mathrm{mmol})$ and benzene $(45 \mathrm{~mL})$ were combined in a flame dried $100 \mathrm{~mL}$ three neck round bottom flask. The reaction mixture was heated to reflux for $8 \mathrm{~h}$. After removal of the solvent under reduced pressure, the residue was dissolved in a minimum volume of dichloromethane and chromatographed by TLC on silica gel. Elution with cyclohexane/ $\mathrm{CH}_{2} \mathrm{Cl}_{2}(2: 1, \mathrm{v} / \mathrm{v})$ developed three bands. The faster moving band afforded $\left[\operatorname{Re}_{2}(\mathrm{CO})_{7}\left(\mu-2,3-\eta^{2}-\mathrm{C}_{3} \mathrm{H}_{2} \mathrm{NS}\right)\left(\eta^{1}-\mathrm{C}_{3} \mathrm{H}_{3} \mathrm{NS}\right)(\mu-\mathrm{H})\right](\mathbf{1})(36 \mathrm{mg}, 24 \%)$ as colorless crystals after recrystallization from hexane/ $\mathrm{CH}_{2} \mathrm{Cl}_{2}$ at $-4{ }^{\circ} \mathrm{C}$. Anal. Calc. for $\mathrm{C}_{13} \mathrm{H}_{6} \mathrm{~N}_{2} \mathrm{O}_{7} \mathrm{~S}_{2} \mathrm{Re}_{2}$ : $\mathrm{C}$, 21.14; H, 0.82. Found: C, 21.36; H, 0.80\%. IR (vCO, $\left.\mathrm{CH}_{2} \mathrm{Cl}_{2}\right): 2096 \mathrm{~s}, 2025$ vs, 1999 vs, 1986 vs, 1950 vs, 1914 vs cm$^{-1} .{ }^{1} \mathrm{H}$ NMR $\left(\mathrm{CDCl}_{3}\right): \delta 8.37(\mathrm{~d}, \mathrm{~J}=1.6 \mathrm{~Hz}, 1 \mathrm{H}), 7.88(\mathrm{~d}, \mathrm{~J}=3.2 \mathrm{~Hz}, 1 \mathrm{H})$, 7.65 (d, J = 3.2 Hz, 1H), 7.41 (dd, J = 3.2, 1.6 Hz, 1H), 7.32 (d, J = 3.2 Hz, 1H), -11.94 (s, 1H). MS (FAB): $m / z 738\left(M^{+}\right)$. The second band gave $\left[\operatorname{Re}_{2}(C O)_{6}\left(\mu-2,3-\eta^{2}-\mathrm{C}_{3} \mathrm{H}_{2} N S\right)\left(\eta^{1-}-\mathrm{NC}_{3} \mathrm{H}_{3} \mathrm{~S}\right)_{2}(\mu-\mathrm{H})\right]$ (3) (13 mg, 9\%) as colorless crystals after recrystallization from hexane $/ \mathrm{CH}_{2} \mathrm{Cl}_{2}$ at $-4{ }^{\circ} \mathrm{C}$. Anal. Calc. for $\mathrm{C}_{15} \mathrm{H}_{9} \mathrm{~N}_{3} \mathrm{O}_{6} \mathrm{~S}_{3} \mathrm{Re}_{2}: \mathrm{C}, 22.64 ; \mathrm{H}, 1.14$. Found: $\mathrm{C}, 22.83 ; \mathrm{H}, 1.37 \%$. IR $\left(v C O, \mathrm{CH}_{2} \mathrm{Cl}_{2}\right)$ : 2024 vs, 2018 vs, 2008 vs, 1911 (vs, br) cm ${ }^{-1} .{ }^{1} \mathrm{H}$ NMR $\left(\mathrm{CDCl}_{3}\right): \delta 8.64$ (d, J = $\left.1.2 \mathrm{~Hz}, 1 \mathrm{H}\right), 8.38$ $(\mathrm{d}, J=1.4 \mathrm{~Hz}, 1 \mathrm{H}), 7.88(\mathrm{~d}, J=3.2 \mathrm{~Hz}, 1 \mathrm{H}), 7.80(\mathrm{~d}, J=2.8 \mathrm{~Hz}, 1 \mathrm{H}), 7.62(\mathrm{dd}, J=3.2,1.4 \mathrm{~Hz}$, $1 \mathrm{H}), 7.34(\mathrm{~m}, 2 \mathrm{H}), 7.29$ (dd, $J=2.8,1.2 \mathrm{~Hz}, 1 \mathrm{H}),-8.66(\mathrm{~s}, 1 \mathrm{H})$. MS (FAB): $\mathrm{m} / \mathrm{z} 795\left(\mathrm{M}^{+}\right)$. The third band gave fac- $\left[\operatorname{Re}(\mathrm{CO})_{3}(\mathrm{Cl})\left(\eta^{1}-\mathrm{NC}_{3} \mathrm{H}_{3} \mathrm{~S}\right)_{2}\right](5)(48 \mathrm{mg}, 24 \%)$ as colorless crystals after recrystallization from hexane $/ \mathrm{CH}_{2} \mathrm{Cl}_{2}$ at $-4{ }^{\circ} \mathrm{C}$. Anal. Calc. for $\mathrm{C}_{9} \mathrm{H}_{6} \mathrm{~N}_{2} \mathrm{O}_{3} \mathrm{~S}_{2} \mathrm{ReCl}$ : C, 22.71; $\mathrm{H}$, 1.27. Found: $\mathrm{C}, 22.97 ; \mathrm{H}, 1.42 \%$. IR $\left(v \mathrm{CO}, \mathrm{CH}_{2} \mathrm{Cl}_{2}\right): 2028 \mathrm{vs}, 1924 \mathrm{~s}, 1889 \mathrm{~s} \mathrm{~cm}{ }^{-1} .{ }^{1} \mathrm{H}$ NMR $\left(\mathrm{CDCl}_{3}\right): \delta 9.38(\mathrm{~s}, 2 \mathrm{H}), 8.11(\mathrm{~d}, \mathrm{~J}=3.2,2 \mathrm{H}), 7.47(\mathrm{~d}, \mathrm{~J}=3.2,2 \mathrm{H}) . \mathrm{MS}(\mathrm{FAB}): \mathrm{m} / \mathrm{z} 476\left(\mathrm{M}^{+}\right)$.

\subsection{REACTION OF $\left[\mathrm{RE}_{2}(\mathrm{CO})_{8}(\mathrm{MECN})_{2}\right]$ WITH 4-METHYLTHIAZOLE}

A benzene solution $(50 \mathrm{~mL})$ of $\left[\mathrm{Re}_{2}(\mathrm{CO})_{8}(\mathrm{MeCN})_{2}\right](150 \mathrm{mg}, 0.22 \mathrm{mmol})$ and 4-methylthiazole (110 $\mathrm{mg}, 1.11 \mathrm{mmol}$ ) was refluxed for $8 \mathrm{~h}$. The solvent was removed under reduced pressure and the residue chromatographed by TLC on silica gel. Elution with cyclohexane/ $\mathrm{CH}_{2} \mathrm{Cl}_{2}(2: 1$, $\mathrm{v} / \mathrm{v})$ developed three bands. The faster moving band gave $\left[\mathrm{Re}_{2}(\mathrm{CO})_{7}\left\{\mu-2,3-\eta^{2}-\mathrm{C}_{3} \mathrm{H}(4-\right.\right.$ $\left.\left.\left.\mathrm{CH}_{3}\right) \mathrm{NS}\right\}\left\{\eta^{1}-\mathrm{NC}_{3} \mathrm{H}_{2}\left(4-\mathrm{CH}_{3}\right) \mathrm{S}\right\}(\mu-\mathrm{H})\right](2)(30 \mathrm{mg}, 18 \%)$ as colorless crystals after recrystallization 
from hexane $/ \mathrm{CH}_{2} \mathrm{Cl}_{2}$ at $-4{ }^{\circ} \mathrm{C}$. Anal. Calc. for $\mathrm{C}_{15} \mathrm{H}_{10} \mathrm{~N}_{2} \mathrm{O}_{7} \mathrm{~S}_{2} \mathrm{Re}_{2}$ : C, 23.50; $\mathrm{H}, 1.31$. Found: $\mathrm{C}$, 23.53; H, 1.36\%. IR ( $v C O, \mathrm{CH}_{2} \mathrm{Cl}_{2}$ ): $2094 \mathrm{~s}, 2025$ vs, 1999 vs, $1984 \mathrm{~s}, 1948 \mathrm{~m}, 1915 \mathrm{~s} \mathrm{~cm}^{-1} .{ }^{1} \mathrm{H}$ $\operatorname{NMR}\left(\mathrm{CDCl}_{3}\right): \delta 7.97(\mathrm{~s}, 1 \mathrm{H}), 7.11(\mathrm{~s}, 1 \mathrm{H}), 6.89(\mathrm{~s}, 1 \mathrm{H}), 2.78(\mathrm{~s}, 3 \mathrm{H}), 2.57(\mathrm{~s}, 3 \mathrm{H}),-11.83(\mathrm{~s}$, $1 \mathrm{H})$. MS (FAB): $\mathrm{m} / \mathrm{z} 766\left(\mathrm{M}^{+}\right)$. The second band gave $\left[\mathrm{Re}_{2}(\mathrm{CO})_{6}\left\{\mu-2,3-\eta^{2}-\mathrm{C}_{3} \mathrm{H}\left(4-\mathrm{CH}_{3}\right) \mathrm{NS}\right\}\left\{\eta^{1-}\right.\right.$ $\left.\mathrm{NC}_{3} \mathrm{H}_{2}\left(4-\mathrm{CH}_{3}\right) \mathrm{S}_{2}(\mu-\mathrm{H})\right]$ (4) (22 mg, 12\%) as colorless crystals after recrystallization from hexane $/ \mathrm{CH}_{2} \mathrm{Cl}_{2}$ at $-4{ }^{\circ} \mathrm{C}$. Anal. Calc. for $\mathrm{C}_{18} \mathrm{H}_{15} \mathrm{~N}_{3} \mathrm{O}_{6} \mathrm{~S}_{3} \mathrm{Re}_{2}$ : C, 25.80; $\mathrm{H}, 1.80$. Found: C, 25.84; $\mathrm{H}, 1.82 \%$. IR ( $v \mathrm{CO}, \mathrm{CH}_{2} \mathrm{Cl}_{2}$ ): 2025 vs, 2017 vs, 2007 vs, 1912 vs cm-1. ${ }^{1} \mathrm{H}$ NMR $\left(\mathrm{CDCl}_{3}\right): \delta 8.77$ (s, 1H), $8.05(\mathrm{~s}, 1 \mathrm{H}), 7.06(\mathrm{~s}, 1 \mathrm{H}), 7.02(\mathrm{~s}, 1 \mathrm{H}), 6.86(\mathrm{~s}, 1 \mathrm{H}), 2.82(\mathrm{~s}, 3 \mathrm{H}), 2.80(\mathrm{~s}, 3 \mathrm{H}), 2.51(\mathrm{~s}$, $3 \mathrm{H}),-8.50(\mathrm{~s}, 1 \mathrm{H})$. MS (FAB): $\mathrm{m} / z \quad 837\left(\mathrm{M}^{+}\right)$. The third band gave fac- $[\operatorname{Re}(\mathrm{CO}))_{3}(\mathrm{Cl})\left\{\mathrm{\eta}^{1}-\mathrm{NC}_{3} \mathrm{H}_{2}(4-\right.$ $\left.\mathrm{CH}_{3}\right) \mathrm{S}_{2}$ ] (6) (10 mg, 9\%) as colorless crystals after recrystallization from hexane $/ \mathrm{CH}_{2} \mathrm{Cl}_{2}$ at $-4{ }^{\circ} \mathrm{C}$. Anal. Calc. for $\mathrm{C}_{11} \mathrm{H}_{10} \mathrm{~N}_{2} \mathrm{O}_{3} \mathrm{~S}_{2} \mathrm{ReCl}$ : C, 26.21; H, 2.00. Found: C, 26.26, H, 1.97\%. IR (vCO, $\left.\mathrm{CH}_{2} \mathrm{Cl}_{2}\right): 2028 \mathrm{vs}, 1923 \mathrm{~s}, 1887 \mathrm{~s} \mathrm{~cm}^{-1} .{ }^{1} \mathrm{H} \mathrm{NMR}\left(\mathrm{CDCl}_{3}\right): \delta 8.63(\mathrm{~s}, 2 \mathrm{H}), 7.91(\mathrm{~s}, 2 \mathrm{H})$, $2.79(\mathrm{~s}, 6 \mathrm{H}) . \mathrm{MS}(\mathrm{FAB}): \mathrm{m} / z 504\left(\mathrm{M}^{+}\right)$.

\subsection{REACTION OF 1 WITH THIAZOLE}

Solid $\mathrm{Me}_{3} \mathrm{NO}$ (2 mg, $0.026 \mathrm{mmol}$ ) was added to a benzene solution ( $15 \mathrm{~mL}$ ) of 1 (20 mg, $0.027 \mathrm{mmol}$ ) and thiazole (12 $\mathrm{mg}, 0.14 \mathrm{mmol}$ ) and the reaction mixture was refluxed for $6 \mathrm{~h}$. The solvent was removed under reduced pressure and the residue chromatographed as above to give 3 (10 $\mathrm{mg}, 45 \%)$.

\subsection{REACTION OF 2 WITH 4-METHYLTHIAZOLE}

A similar reaction to that above of $2(25 \mathrm{mg}, 0.033 \mathrm{mmol})$, 4-methylthiazole (16 mg, $0.16 \mathrm{mmol})$ and $\mathrm{Me}_{3} \mathrm{NO}$ (2.5 mg, $0.033 \mathrm{mmol}$ ) followed by similar work-up gave 4 (11 mg, 40\%).

\subsection{X-RAY STRUCTURE DETERMINATION FOR COMPOUNDS 1 AND 2}

Single crystals of compounds 1 and 2 suitable for $X$-ray crystallography were grown from a $\mathrm{CH}_{2} \mathrm{Cl}_{2}$ solution containing each compound that had been layered with hexane.

Crystallographic data for compounds 1 and $\mathbf{2}$ were collected at 150(2) K, using a FAST area detector diffractometer and Mo Ka radiation $(\lambda=0.71073 \AA)$. Empirical absorption corrections were applied to the data sets using multiple and symmetry-related data measurements via the program SORTAV. ${ }^{21,22}$ The unit cell parameters were determined from all observed reflections in a $\theta$ range of $3-10^{\circ}$ and refined using the entire data set. The structures were solved by direct methods (SHELXS-97) ${ }^{23}$ and refined on $F^{2}$ by full matrix least-squares (SHELXL-97) ${ }^{24}$ using all unique data. The bridging hydrides in $\mathbf{1}$ and $\mathbf{2}$ were located from a difference map but not refined. All non-hydrogen atoms were refined anisotropically. The hydrogen atoms were included in calculated positions (riding model) with $U_{\text {iso }}$ set at 1.2 times the $U_{\text {eq }}$ of the parent 
atom. All crystal data along with experimental conditions and refinement details are summarized in Table 1.

Table 1. Crystallographic data and structure refinementa for 1 and 2

\begin{tabular}{|c|c|c|}
\hline & 1 & 2 \\
\hline Empirical formula & $\mathrm{C}_{13} \mathrm{H}_{6} \mathrm{~N}_{2} \mathrm{O}_{7} \mathrm{Re}_{2} \mathrm{~S}_{2}$ & $\mathrm{C}_{15} \mathrm{H}_{10} \mathrm{~N}_{2} \mathrm{O}_{7} \mathrm{Re}_{2} \mathrm{~S}_{2}$ \\
\hline Formula weight & 738.72 & 766.77 \\
\hline Crystal system & Orthorhombic & Triclinic \\
\hline Space group & $P 2(1) 2(1) 2(1)$ & $\mathrm{P}^{-}$ \\
\hline$a(\AA)$ & $10.6925(2)$ & $8.196(4)$ \\
\hline$b(\AA)$ & $11.7996(4)$ & $15.323(5)$ \\
\hline$c(\AA)$ & $14.5071(3)$ & $16.922(5)$ \\
\hline$\alpha\left(^{\circ}\right)$ & 90 & $100.40(2)$ \\
\hline$\beta\left(^{\circ}\right)$ & 90 & $93.02(2)$ \\
\hline$V\left({ }^{\circ}\right)$ & 90 & $95.92(3)$ \\
\hline Volume $\left(\AA^{3}\right)$ & $1830.32(8)$ & 2073.6(14) \\
\hline$Z$ & 4 & 4 \\
\hline$D_{\text {calc }}\left(\mathrm{Mg} / \mathrm{m}^{3}\right)$ & 2.681 & 2.456 \\
\hline$\mu(\mathrm{Mo} \mathrm{K \alpha})\left(\mathrm{mm}^{-1}\right)$ & 13.480 & 11.904 \\
\hline$F\left(\begin{array}{lll}0 & 0 & 0\end{array}\right)$ & 1344 & 1408 \\
\hline Crystal size $\left(\mathrm{mm}^{3}\right)$ & $0.10 \times 0.10 \times 0.08$ & $0.20 \times 0.18 \times 0.15$ \\
\hline$\theta$ Range $\left({ }^{\circ}\right)$ & $3.30-27.48$ & $1.65-25.29$ \\
\hline Index ranges & $\begin{array}{l}-13 \leqslant h \leqslant 13,-15 \leqslant k \leqslant 15 \\
-18 \leqslant l \leqslant 18\end{array}$ & $\begin{array}{l}-9 \leqslant h \leqslant 9,-18 \leqslant k \leqslant 18 \\
0 \leqslant l \leqslant 20\end{array}$ \\
\hline Reflections collected & 25548 & 7477 \\
\hline Independent reflections $\left[R_{\text {int }}\right]$ & $2370[0.0568]$ & $7477[0.0000]$ \\
\hline Maximum and minimum transmission & 0.4118 and 0.3458 & 0.2683 and 0.1993 \\
\hline Data/restraints/parameters & $2370 / 0 / 235$ & $7477 / 0 / 509$ \\
\hline Goodness-of-fit on $F^{2}$ & 1.038 & 0.900 \\
\hline Final $R$ indices $[I>2 \sigma(I)]$ & $R_{1}=0.0259, w R_{2}=0.0708$ & $R_{1}=0.0477, w R_{2}=0.0978$ \\
\hline$R$ indices (all data) & $R_{1}=0.0261, w R_{2}=0.0710$ & $R_{1}=0.1066, w R_{2}=0.1096$ \\
\hline $\begin{array}{l}\text { Largest difference in peak and hole } \\
\left(\mathrm{e} \AA^{-3}\right) \\
\text { aDetails in common: X-radiation, Mo K } \\
\text { least-squares on } F^{2} \text {. Flack parameter } \mathrm{f}\end{array}$ & 1.606 and -2.049 & 1.422 and -1.882 \\
\hline
\end{tabular}

\subsection{X-RAY STRUCTURE DETERMINATION COMPOUNDS 3-5}

Single crystals of compounds 3-5 suitable for X-ray crystallography were grown from a $\mathrm{CH}_{2} \mathrm{Cl}_{2}$ solution containing each compound that had been layered with hexane. Single crystals of compounds of 3-5 were mounted on a Nylon fiber with a mineral oil, and diffraction data were collected at 150(2) K on a Bruker AXS SMART diffractometer equipped with an APEX 
CCD detector using graphite-monochromated Mo Ka radiation $(\lambda=0.71073 \AA)$. Integration of intensities and data reduction was performed using SAINTprogram.17 Multi-scan absorption correction was applied using SADABS procedure. ${ }^{18}$ The structures were solved by direct methods ${ }^{19}$ and refined by full-matrix least squares on $\mathrm{F}^{2}{ }^{20}$ All non-hydrogen atoms were refined anisotropically. Positions of hydrogen atoms were calculated geometrically and were included into refinement with $B$ (iso) $=1.2 B$ (iso/eq) of an adjacent carbon atom using a riding model. The bridging hydride was localized in a difference Fourier map and was positionally refined in isotropic approximation. All pertinent crystal data and other experimental conditions and refinement details are summarized in Table 2.

Table 2. Crystallographic data and structure refinementa for $3-5$

\begin{tabular}{|c|c|c|c|}
\hline & 3 & 4 & 5 \\
\hline Empirical formula & $\mathrm{C}_{15} \mathrm{H}_{9} \mathrm{~N}_{3} \mathrm{O}_{6} \mathrm{Re}_{2} \mathrm{~S}_{3}$ & $\mathrm{C}_{18} \mathrm{H}_{15} \mathrm{~N}_{3} \mathrm{O}_{6} \mathrm{Re}_{2} \mathrm{~S}_{3}$ & $\mathrm{C}_{9} \mathrm{H}_{6} \mathrm{ClN}_{2} \mathrm{O}_{3} \mathrm{ReS}_{2}$ \\
\hline Formula weight & 795.83 & 837.91 & 475.93 \\
\hline Crystal system & Monoclinic & Triclinic & Monoclinic \\
\hline Space group & $C 2 / c$ & $\mathrm{P} 1^{-}$ & $C 2 / C$ \\
\hline$a(\AA)$ & $15.622(3)$ & $8.7422(17)$ & $7.2554(9)$ \\
\hline$b(\AA)$ & $8.5209(19)$ & $10.2419(19)$ & $14.3465(17)$ \\
\hline$c(\AA)$ & $16.280(4)$ & $14.702(3)$ & $12.7901(15)$ \\
\hline$\alpha\left(^{\circ}\right)$ & 90 & $89.176(3)$ & 90 \\
\hline$\beta\left({ }^{\circ}\right)$ & 104.855(3) & 79.994(3) & $91.862(2)$ \\
\hline$V\left({ }^{\circ}\right)$ & 90 & $67.047(2)$ & 90 \\
\hline Volume $\left(\AA^{3}\right)$ & 2094.8(8) & $1191.6(4)$ & 1330.6(3) \\
\hline$z$ & 4 & 2 & 4 \\
\hline$D_{\text {calc }}\left(\mathrm{Mg} / \mathrm{m}^{3}\right)$ & 2.523 & 2.335 & 2.376 \\
\hline$\mu(\mathrm{Mo} \mathrm{Ka})\left(\mathrm{mm}^{-1}\right)$ & 11.883 & 10.451 & 9.645 \\
\hline$F\left(\begin{array}{lll}0 & 0 & 0\end{array}\right)$ & 1464 & 780 & 888 \\
\hline Crystal size $\left(\mathrm{mm}^{3}\right)$ & $0.40 \times 0.25 \times 0.21$ & $0.30 \times 0.27 \times 0.20$ & $0.35 \times 0.25 \times 0.15$ \\
\hline$\theta$ Range $\left({ }^{\circ}\right)$ & $2.59-31.84$ & $1.41-31.87$ & $2.84-31.93$ \\
\hline Index ranges & $\begin{array}{l}-23 \leqslant h \leqslant 22,0 \leqslant k \leqslant 12 \\
0 \leqslant I \leqslant 23\end{array}$ & $\begin{array}{l}-12 \leqslant h \leqslant 12 \\
-15 \leqslant k \leqslant 15,0 \leqslant l \leqslant 21\end{array}$ & $\begin{array}{l}-10 \leqslant h \leqslant 10,0 \leqslant k \leqslant 21 \\
0 \leqslant l \leqslant 18\end{array}$ \\
\hline Reflections collected & 16791 & 19224 & 10816 \\
\hline Independent reflections [ $\left.R_{\mathrm{int}}\right]$ & 3315 [0.0317] & 7522 [0.0242] & 2180 [0.0269] \\
\hline $\begin{array}{l}\text { Maximum and minimum } \\
\text { transmission }\end{array}$ & 0.1893 and 0.0874 & 0.2290 and 0.1456 & 0.3256 and 0.1333 \\
\hline Data/restraints/parameters & $3315 / 30 / 138$ & $7522 / 19 / 336$ & $2180 / 11 / 91$ \\
\hline Goodness-of-fit on $F^{2}$ & 1.034 & 0.985 & 1.096 \\
\hline Final $R$ indices $[I>2 \sigma(I)]$ & $R_{1}=0.0172, w R_{2}=0.0389$ & $R_{1}=0.0222, w R_{2}=0.0545$ & $R_{1}=0.0155, w R_{2}=0.0374$ \\
\hline$R$ indices (all data) & $R_{1}=0.0195, w R_{2}=0.0397$ & $R_{1}=0.0256 w R_{2}=0.0557$ & $R_{1}=0.0160 w R_{2}=0.0376$ \\
\hline $\begin{array}{l}\text { Largest difference in peak } \\
\text { and hole }\left(\mathrm{e} \AA^{-3}\right)\end{array}$ & 1.474 and -1.345 & 2.557 and -1.240 & 0.757 and -1.119 \\
\hline
\end{tabular}


aDetails in common: X-radiation, Mo Ka $(\lambda=0.71073 \AA)$, temperature $(K) 100(2)$, refinement method: full-matrix least-squares on $\mathrm{F}^{2}$.

\section{RESULTS AND DISCUSSION}

Treatments of $\left[\mathrm{Re}_{2}(\mathrm{CO})_{8}(\mathrm{MeCN})_{2}\right]$ with five equivalents of thiazole and 4-methylthiazole in refluxing benzene, followed by chromatographic separation, lead to the formation of three new sets of compounds $\left[\mathrm{Re}_{2}(\mathrm{CO})_{7}\left\{\mu-2,3-\eta^{2}-\mathrm{C}_{3} \mathrm{H}(4-\mathrm{R}) \mathrm{NS}\right\}\left\{\eta^{1}-\mathrm{NC}_{3} \mathrm{H}_{2}(4-\mathrm{R}) \mathrm{S}\right\}(\mu-\mathrm{H})\right](\mathbf{1}, \mathrm{R}=\mathrm{H}, 24 \%$; 2 , $\left.\mathrm{R}=\mathrm{CH}_{3}, 18 \%\right),\left[\mathrm{Re}_{2}(\mathrm{CO}){ }_{6}\left\{\mu-2,3-\eta^{2}-\mathrm{C}_{3} \mathrm{H}(4-\mathrm{R}) \mathrm{NS}\right\}\left\{\eta^{1-} \mathrm{NC}_{3} \mathrm{H}_{2}(4-\mathrm{R}) \mathrm{S}\right\}_{2}(\mu-\mathrm{H})\right](\mathbf{3}, \mathrm{R}=\mathrm{H}, \mathbf{9 \%} ; \mathbf{4}$, $\left.\mathrm{R}=\mathrm{CH}_{3}, 12 \%\right)$ and fac $-\left[\mathrm{Re}(\mathrm{CO})_{3}(\mathrm{Cl})\left\{\mathrm{\eta}^{1}-\mathrm{NC}_{3} \mathrm{H}_{2}(4-\mathrm{R}) \mathrm{S}\right\}_{2}\right]\left(5, \mathrm{R}=\mathrm{H}, 24 \% ; \mathbf{6}, \mathrm{R}=\mathrm{CH}_{3}, 9 \%\right)$ (Scheme 3).

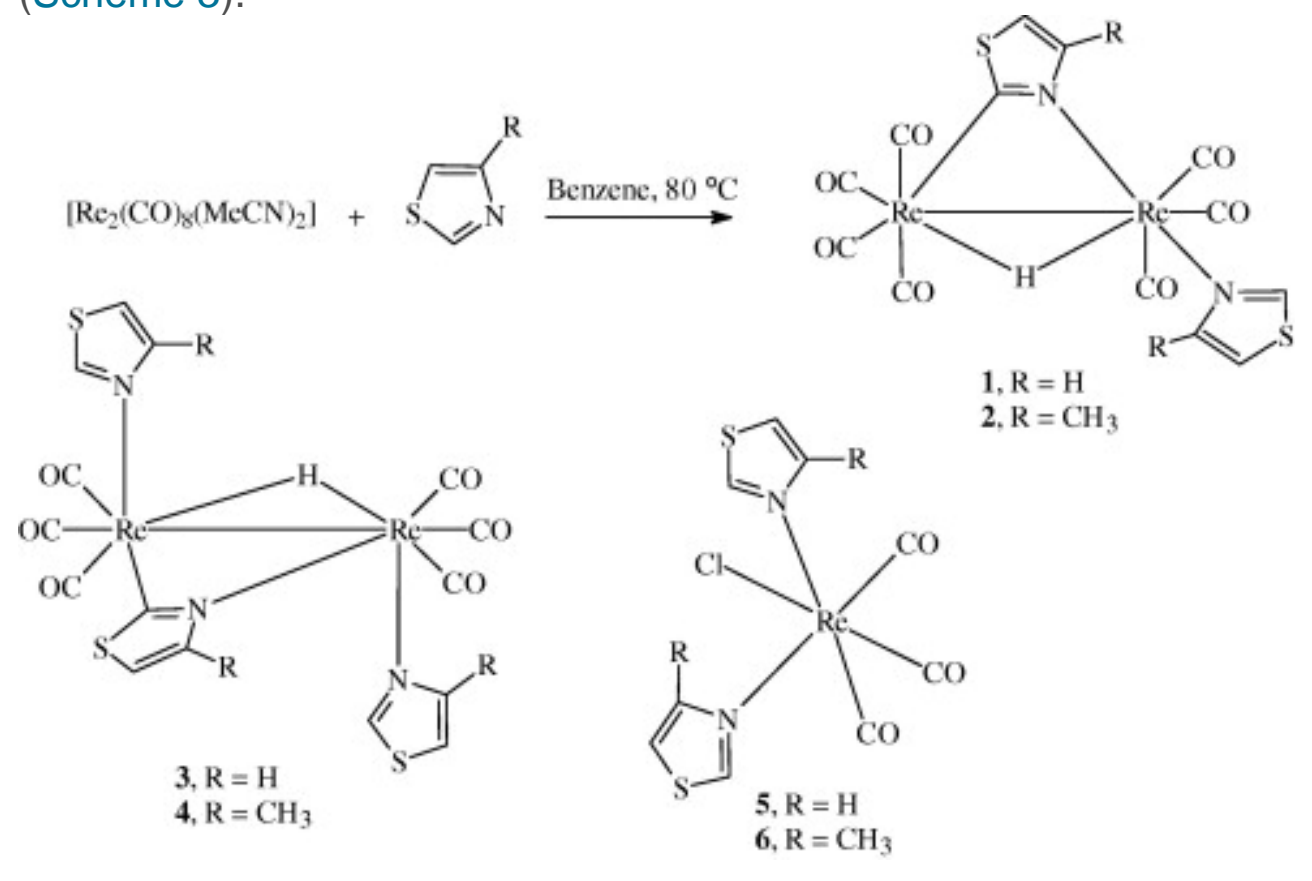

Scheme 3.

Compounds 1 and $\mathbf{2}$ have been characterized by a combination of IR, ${ }^{1 \mathrm{H}}$ NMR, mass spectral data, elemental analysis and single crystal X-ray diffraction studies. The structure of $\mathbf{1}$ is analogous to that of $\mathbf{2}$, and both compounds are isostructural. The structure of $\mathbf{1}$ is depicted in Fig. 1 and selected bond distances and angles are listed in the caption. In the crystals of $\mathbf{2}$, there are two crystallographically-independent molecules in the asymmetric unit. The respective bond lengths and angles in the two molecules show only minor variations, but the molecules differ in their relative orientations in the unit cell, most probably for efficient packing. The structure of one of these molecules is shown in Fig. 2 and selected bond distances are listed in the caption. Both structures of $\mathbf{1}$ and $\mathbf{2}$ consist of direhenium core with seven terminal carbonyl ligands, a bridging thiazolide ligand, one $\mathrm{N}$-coordinated $\eta^{1}$-thiazole ligand and $\mathrm{a}$ bridging hydride ligand. The $\mu-\eta^{2}$-thiazolide ligand is coordinated in a similar way to those observed in $\left[\mathrm{Os}_{3}(\mathrm{CO})_{10}\left(\mu-2,3-\eta^{2}-\mathrm{C}=\mathrm{NCH}=\mathrm{CHS}-\right)(\mu-\mathrm{H})\right]^{14}$ and $\left[\mathrm{Os}_{3}(\mathrm{CO})_{10}\left(\mu-2,3-\eta^{2}-\mathrm{C}=\mathrm{NCMe}\right.\right.$ 
$=\mathrm{C}-\mathrm{HS}-)(\mu-\mathrm{H})] \cdot{ }^{13}$ Each Re atom attains a slightly distorted octahedral coordination sphere through the terminal carbonyl ligands, the bridging hydride, $\eta^{1}$-thiazole and $\mu$ - $\eta^{2}$-thiazolide ligands. The $\eta^{1}$-thiazole and terminal $\mathrm{CO}$ groups at both rhenium centers show an ecliptic arrangement. The position of the bridging hydride ligand was located (not refined) from the $\Delta F$ map and found opposite the thiazolide bridge in between the $\mathrm{C}(2)$ and $\mathrm{C}(5)$ carbonyls in 1 and between $C(1)$ and $C(5)$ carbonyls in 2 . Further evidene in support of the hydride being bridging the Re-Re edge is supported by the large Re-Re-C(1)/C(2) and Re-Re-C(5) bond angles, 107.7(3)-112.2(3) ${ }^{\circ}$. The resulting five-membered central $\mathrm{Re}_{2} \mathrm{HCN}$ ring is almost planar. The Re-Re bond distance $\{3.2696(5) \AA$ for 1 and 3.2546(12) $\AA$ for 2$\}$ is significantly longer than that observed in $\left[\operatorname{Re}_{2}(C O)_{10}\right]\{3.0413(11) \AA\}^{25}$ but compares well with those observed in structurally characterized dirhenium compounds $\left[\operatorname{Re}_{2}(\mathrm{CO})_{8}\left(\mu-\mathrm{N}_{2} \mathrm{C}_{12} \mathrm{H}_{9}\right)(\mu-\mathrm{H})\right]\{3.256(12) \AA\}[1 \mathrm{~b}]$, $\left[\mathrm{Re}_{2}(\mathrm{CO})_{8}\left(\mu-\mathrm{NC}_{5} \mathrm{H}_{4}\right)(\mu-\mathrm{H})\right]\{3.2088(4) \AA\}^{5 a}$ which also contain hydride bridged Re-Re single bonds. According to electron counting procedures, they should both contain a Re-Re single bond so that each rhenium atom can attain the usual 18-electron configuration. The $\mu-\eta^{2-}$ thiazolide ligand donates three electrons via a 2-electron donor bond from $\mathrm{Re}-\mathrm{N}(1)\{\operatorname{Re}(2)-$ $\mathrm{N}(1)=2.150(7) \AA$ for 1 and $\operatorname{Re}(1)-\mathrm{N}(1)=2.171(11) \AA$ for 2$\}$ and a metal-carbon $\sigma$-bond between $\mathrm{C}(8)$ and $\operatorname{Re}\{\operatorname{Re}(1)-C(8)=2.149(10) \AA$ for 1 and $\operatorname{Re}(2)-C(8)=2.168(14) \AA$ for 2$\}$. The 2-electron donor $\eta^{1}$-thiazole/4-methylthiazole is coordinated through the nitrogen atom which occupies an equatorial site on $\operatorname{Re}(2)$ for 1 and $\operatorname{Re}(1)$ for 2 . The $\operatorname{Re}-\mathrm{N}$ bond lengths involving the $\eta^{1}$-thiazole ligand $\{\operatorname{Re}(2)-\mathrm{N}(2)=2.201(8) \AA$ for 1 and $\operatorname{Re}(1)-\mathrm{N}(2) 2.242(11) \AA$ for 2$\}$ is longer than the Re-N(1) bond length involving the bridging thiazolide ligand. Overall, the structures of 1 and 2 are comparable to that of $\left[\mathrm{Re}_{2}(\mathrm{CO})_{7}\left\{\mu-\mathrm{NC}_{5} \mathrm{H}_{4}\right\}\left(\mathrm{Me}_{3} \mathrm{NO}\right)(\mu-\mathrm{H})\right]$ in which the pyridyl and the hydride bridge the $\mathrm{Re}-\mathrm{Re}$ single bond in opposite site and a $\mathrm{Me}_{3} \mathrm{NO}$ is attached to the Re which is also bonded to the pyridyl nitrogen. ${ }^{5 a}$

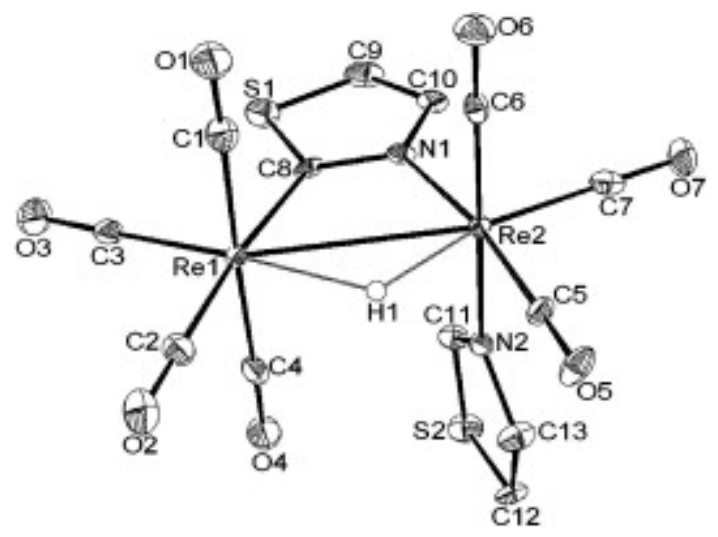

Fig. 1. Molecular structure of $\left[\operatorname{Re}_{2}(\mathrm{CO})_{7}\left(\mu-2,3-\eta^{2}-\mathrm{C}_{3} \mathrm{H}_{2} \mathrm{NS}\right)\left(\eta^{1-} \mathrm{NC}_{3} \mathrm{H}_{3} \mathrm{~S}\right)(\mu-\mathrm{H})\right]$ (1) showing $35 \%$ probability thermal ellipsoids. All hydrogen atoms except the hydrido ligand are omitted for clarity. Selected bond distances $(\AA)$ and angles $\left({ }^{\circ}\right): \operatorname{Re}(1)-\operatorname{Re}(2)=3.2696(5), \operatorname{Re}(2)-\mathrm{N}(1)=2.150(7), \operatorname{Re}(2)-\mathrm{N}(2)=2.201(8)$, $\operatorname{Re}(1)-C(8)=2.149(10), \operatorname{Re}-\mathrm{C}(\mathrm{CO}) \mathrm{av}=1.946(2), \mathrm{C}-\mathrm{O}(\mathrm{av})=1.147(2), \mathrm{C}(8)-\operatorname{Re}(1)-\operatorname{Re}(2)=61.3(3)$, $\mathrm{N}(1)-\operatorname{Re}(2)-\operatorname{Re}(1)=64.5(2), \mathrm{N}(1)-\operatorname{Re}(2)-\mathrm{N}(2)=84.1(3), \mathrm{C}(1)-\operatorname{Re}(1)-\operatorname{Re}(2)=86.8(3), \mathrm{C}(2)-\operatorname{Re}(1)-$ $\operatorname{Re}(2)=112.2(3), C(3)-\operatorname{Re}(1)-\operatorname{Re}(2)=155.3(4), C(4)-\operatorname{Re}(1)-\operatorname{Re}(2)=91.0(4), C(5)-\operatorname{Re}(2)-$ 

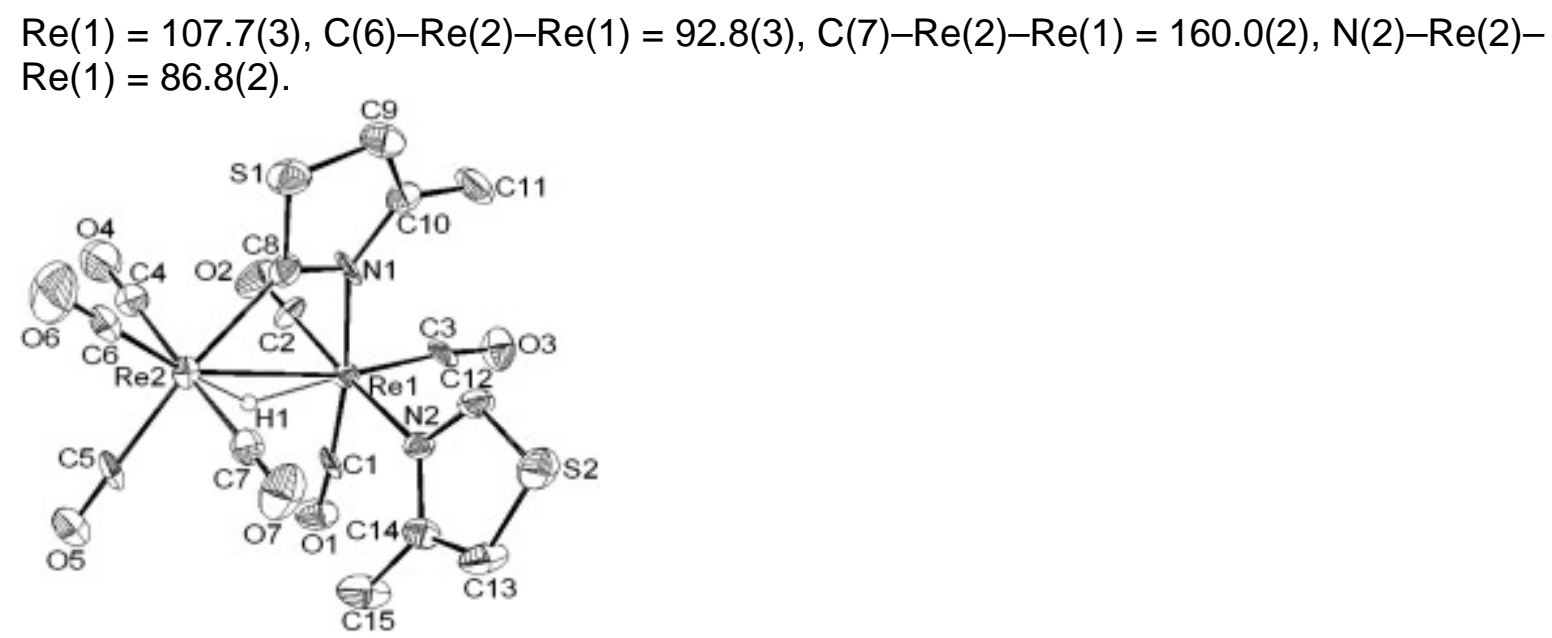

Fig. 2. Molecular structure of one of the crystallographically independent molecules of $\left[\operatorname{Re}_{2}(\mathrm{CO})_{7}\{\mu-2,3-\right.$ $\left.\left.\eta^{2}-\mathrm{C}_{3} \mathrm{H}\left(4-\mathrm{CH}_{3}\right) \mathrm{NS}\right\}\left\{\eta^{1}-\mathrm{NC}_{3} \mathrm{H}_{2}\left(4-\mathrm{CH}_{3}\right) \mathrm{S}\right\}(\mu-\mathrm{H})\right](2)$ showing $35 \%$ probability thermal ellipsoids. All hydrogen atoms except the hydrido ligand are omitted for clarity. Selected bond lengths $(\AA)$ and angles $\left(^{\circ}\right)$ : $\operatorname{Re}(1)-\operatorname{Re}(2)=3.2546(12), \operatorname{Re}(1)-\mathrm{N}(1)=2.171(11), \operatorname{Re}(1)-\mathrm{N}(2)=2.242(11), \operatorname{Re}(2)-\mathrm{C}(8)=2.168(14)$, $\mathrm{N}(1)-\mathrm{C}(8)=1.323(16), \mathrm{Re}-\mathrm{CO}(\mathrm{av})=1.932(2), \mathrm{C}-\mathrm{O}(\mathrm{av})=1.147(17), \mathrm{C}(8)-\operatorname{Re}(2)-\operatorname{Re}(1)=62.1(4)$, $\mathrm{N}(1)-\operatorname{Re}(1)-\operatorname{Re}(2)=64.9(2), \mathrm{N}(1)-\operatorname{Re}(1)-\mathrm{N}(2)=84.5(4), \mathrm{C}(1)-\operatorname{Re}(1)-\operatorname{Re}(2)=108.5(4), \mathrm{C}(2)-\operatorname{Re}(1)-$ $\operatorname{Re}(2)=93.8(4), C(3)-\operatorname{Re}(1)-\operatorname{Re}(2)=163.8(4), C(4)-\operatorname{Re}(2)-\operatorname{Re}(1)=88.1(6), C(5)-\operatorname{Re}(2)-$ $\operatorname{Re}(1)=108.4(5), C(6)-\operatorname{Re}(2)-\operatorname{Re}(1)=156.5(4), C(7)-\operatorname{Re}(2)-\operatorname{Re}(1)=93.5(4), N(2)-\operatorname{Re}(1)-$ $\operatorname{Re}(2)=84 \cdot 9(3)$.

The spectroscopic data in solution for $\mathbf{1}$ and $\mathbf{2}$ are in accord with the structures observed in solid-state. The IR spectrum of $\mathbf{1}$ in the carbonyl stretching region resembles that for $\mathbf{2}$ and indicates that only terminal carbonyl groups are present in both of them. The ${ }^{1} \mathrm{H}$ NMR spectrum of 1 in the aromatic region contains five well-separated signals each integrating for one proton indicating the presence of two non-equivalent thiazole rings. The absence of a signal for $\mathrm{C}(2)-$ $\mathrm{H}$ and a singlet at $\delta-11.94$ due to a bridging hydride $\mathrm{Re}-\mathrm{H}-\mathrm{Re}$, suggests a $\mathrm{C}-\mathrm{H}$ bond cleavage of one of the thiazole rings. In addition to the hydride signal at $\delta-11.83$ the ${ }^{1} \mathrm{H}$ NMR spectrum of 2 shows two singlets at $\delta 2.78$ and 2.57 due to the methyl protons of $\eta^{1-4-}$ methylthiazole and $\mu-\eta^{2}-4$-methylthiazolide ligands. The chemical shift of the hydride ligands in both $\mathbf{1}$ and $\mathbf{2}$ is typical for hydrido bridged dirhenium carbonyl complexes. ${ }^{3,4,5,6,7}$ The mass spectra of $\mathbf{1}$ and $\mathbf{2}$ exhibit molecular ion peaks at $m / z 738$ for $\mathbf{1}$ and 766 for $\mathbf{2}$, respectively, and fragmentation peaks due to the sequential loss of seven carbonyl groups are also observed.

Compounds $\mathbf{3}$ and $\mathbf{4}$ have been characterized by a combination of IR, ${ }^{1} \mathrm{H}$ NMR, mass spectral data, elemental and single crystal X-ray diffraction analyses. The molecular structures of $\mathbf{3}$ and $\mathbf{4}$ are shown in Fig. 3, Fig. 4, respectively, and selected bond distances and angles are listed in the caption. Both compounds contain two $\operatorname{Re}(\mathrm{CO})_{3}$ groups that are simultaneously bridged by a 4-methylthiazilide and a hydride ligand. The 4-methylthiazolide and the hydride is coordinated in $\mathbf{3}$ and $\mathbf{4}$ in a similar way to those observed in the crystal structures of $\mathbf{1}$ and $\mathbf{2}$. Each $\mathrm{Re}$ atom also contains a $\eta^{1}$-thiazole ligand coordinated through the nitrogen atom and 
occupies an equatorial site. The $\eta^{1}$-thiazole ligand at both rhenium centers shows an ecliptic arrangement, the largest $\mathrm{N}(1)-\mathrm{Re}(1)-\operatorname{Re}(1 \mathrm{~A})-\mathrm{N}(2)$ torsion angle being $92.0(1)^{\circ}$ for

compound $\mathbf{3}$. The bridging hydride ligands in $\mathbf{3}$ and $\mathbf{4}$ were located and refined with isotropic thermal parameters. They are positioned between the equatorial CO groups opposite to the thiazolide bridge and typical large $\operatorname{Re}(1 \mathrm{~A})-\mathrm{Re}(2)-\mathrm{C}(8)$ and $\mathrm{Re}(2)-\operatorname{Re}(1)-\mathrm{C}$ angles of 116.99(8) and 107.70(10) are consistent with the presence of hydride ligand bridging the $\mathrm{Re}-\mathrm{Re}$ edge. The Re-Re bond distances are $\{3.3153(7) \AA$ for 3 and 2.729(12) $\AA$ for 4$\}$ comparable to the $\mathrm{Re}-\mathrm{Re}$ bond distances observed in 1 and 2 . The $\mathrm{Re}-\mathrm{N}$ bond distances involving the terminally coordinated thiazole ligands $\{2.204(2) ; 2.266(6) \AA\}$ closely resemble to that of $N(2)-\operatorname{Re}(1 A)$ $\{2.266(6) \AA\}$ of the bridging thiazolide ligand. The $\operatorname{Re}(1)-C(1)\{2.141(4) \AA\}$ bond distance is longer than the $\{\operatorname{Re}(1)-C(4) 2.050(6) \AA\}$ bond distance in compound 3 while the $\operatorname{Re}(2)-N(1)$ [2.198(3) A] bond distance is shorter compared to that of $\operatorname{Re}(1 \mathrm{~A})-\mathrm{N}(2) 2.266(6)$ bond distance in 3. This is probably due to the steric effect of methyl group present at position 4 rather than hydrogen in thiazole ring. Having the ecliptic arrangement of $\eta^{1-4-m e t h y l t h i a z o l e ~ l i g a n d s, ~ t h e ~}$ largest $\mathrm{N}(2)-\operatorname{Re}(1)-\operatorname{Re}(2)-\mathrm{N}(1)$ torsion angle $89.1^{\circ}$ observed for $\mathrm{N}(2)$ and $\mathrm{N}(3)$ closely resembles to that for $\mathrm{N}(1)$ and $\mathrm{N}(2) \# 1$ in 3.

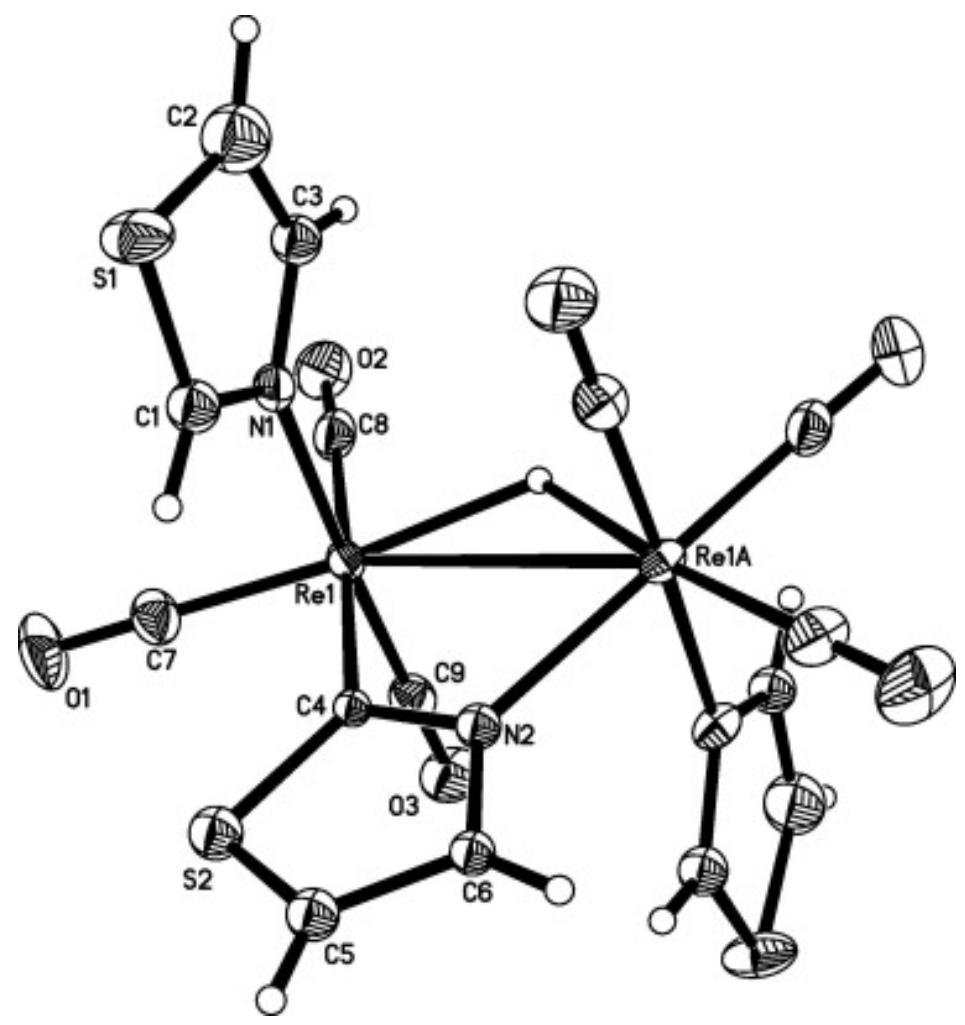

Fig. 3. Molecular structure of complex $\left[(\mu-\mathrm{H}) \mathrm{Re}_{2}(\mathrm{CO})_{6}\left(\mu-2,3-\eta^{2}-\mathrm{C}_{3} \mathrm{H}_{2} \mathrm{NS}\right)\left\{\eta^{1}-\mathrm{NC}_{3} \mathrm{H}_{3} \mathrm{~S}\right\}_{2}\right](3, \mathrm{R}=\mathrm{H} ; 4, \mathrm{R}=4-$ $\left.\mathrm{CH}_{3}\right)$ 3. Selected bond lengths $(\AA)$ and angles $\left({ }^{\circ}\right)$ : $\operatorname{Re}(1)-\operatorname{Re}(1 A)=3.3153(7), \operatorname{Re}(1)-\mathrm{N}(1)=2.204(2)$, $\mathrm{Re}(1)-\mathrm{C}(4)=2.050(6), \operatorname{Re}(1 \mathrm{~A})-\mathrm{N}(2) \# 1=2.266(6), \operatorname{Re}(1 \mathrm{~A})-\mathrm{N}(2)=2.266(6), \operatorname{Re}(1)-\mathrm{H}(10)=1.97(2)$, $\mathrm{C}(4)-\operatorname{Re}(1)-\operatorname{Re}(1 \mathrm{~A})=64.60(18), \mathrm{N}(2)-\operatorname{Re}(1 \mathrm{~A})-\operatorname{Re}(1)=64.53(12), \mathrm{C}(4)-\operatorname{Re}(1)-\mathrm{N}(1)$ 87.83(19), N(2)$\operatorname{Re}(1 \mathrm{~A})-\mathrm{N}(2) \# 1=85.83(16), \mathrm{N}(1)-\operatorname{Re}(1)-\operatorname{Re}(1 \mathrm{~A})=84.70(6), \operatorname{Re}(1 \mathrm{~A})-\operatorname{Re}(1)-\mathrm{C}(7)=154.19(10)$, $\operatorname{Re}(1 \mathrm{~A})-\operatorname{Re}(1)-C(8)=116.99(8), \operatorname{Re}(1 \mathrm{~A})-\operatorname{Re}(1)-C(9)=92.29(8)$. 


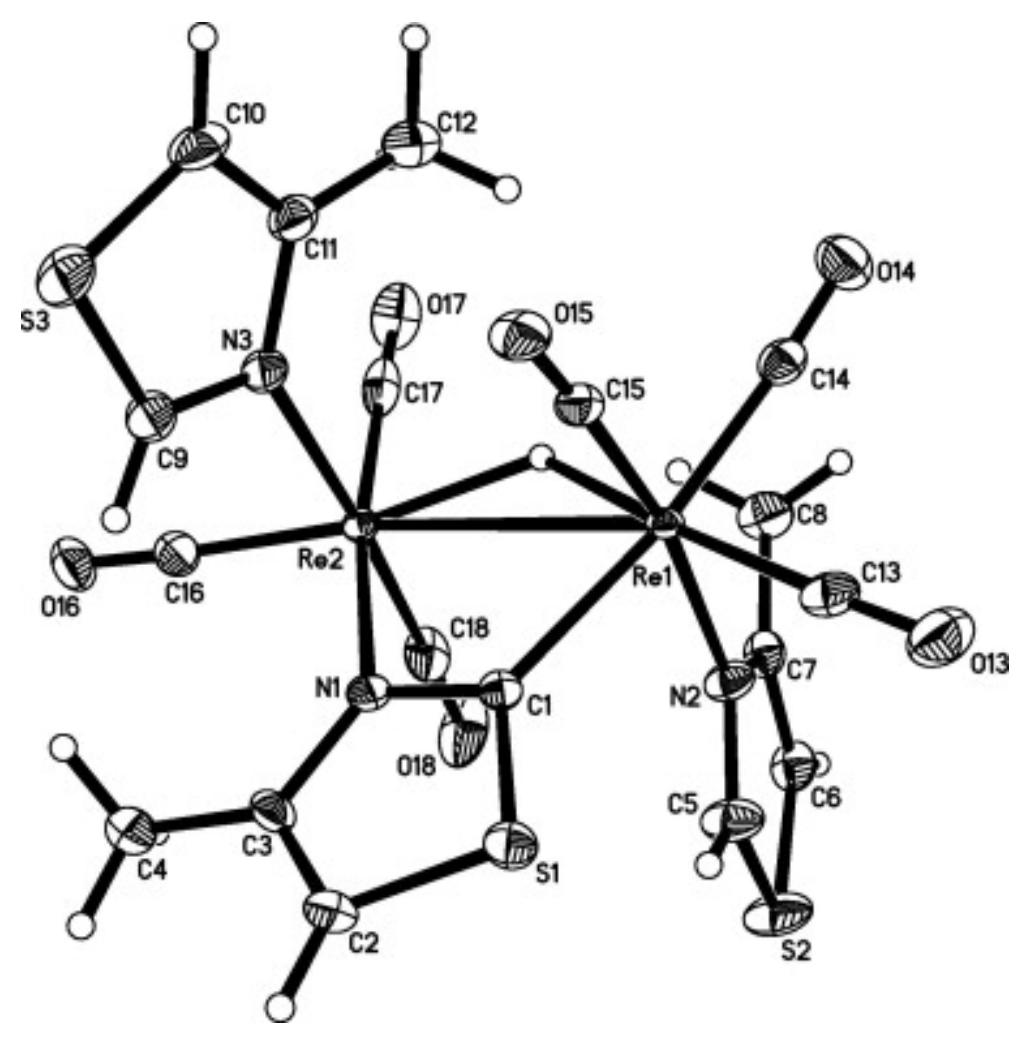

Fig. 4. Molecular structure of complex $\left[(\mu-\mathrm{H}) \mathrm{Re}_{2}(\mathrm{CO})_{6}\left\{\mu-2,3-\eta^{2}-\mathrm{C}_{3} \mathrm{H}\left(4-\mathrm{CH}_{3}\right) \mathrm{NS}\right\}\left\{\eta^{1}-\mathrm{NC}_{3} \mathrm{H}_{2}\left(4-\mathrm{CH}_{3}\right) \mathrm{S}\right\}_{2}\right](4)$. Selected bond lengths $(\AA)$ and angles $\left(^{\circ}\right)$ : $\operatorname{Re}(1)-\operatorname{Re}(2)=3.2729(12), \operatorname{Re}(2)-N(3)=2.229(3), \operatorname{Re}(1)-$ $\mathrm{C}(1)=2.141(4), \operatorname{Re}(2)-\mathrm{N}(1)=2.198(3), \operatorname{Re}(1)-\mathrm{N}(2)=2.252(3), \mathrm{C}(1)-\mathrm{Re}(1)-\operatorname{Re}(2)=62.34(10), N(1)-$ $\operatorname{Re}(2)-\operatorname{Re}(1)=64.49(9), \mathrm{C}(1)-\operatorname{Re}(1)-\mathrm{N}(2)=85.50(14), \mathrm{N}(1)-\operatorname{Re}(2)-\mathrm{N}(3)=86.80(12), \mathrm{N}(3)-\operatorname{Re}(2)-$ $\operatorname{Re}(1)=86.56(8), \operatorname{Re}(2)-\operatorname{Re}(1)-C(13)=158.65(11), \operatorname{Re}(2)-\operatorname{Re}(1)-C(14)=109.31(10), \operatorname{Re}(1)-\operatorname{Re}(2)-$ $C(16)=165.99(11), \operatorname{Re}(1)-\operatorname{Re}(2)-C(17)=107.70(10), \operatorname{Re}(1)-\operatorname{Re}(2)-C(18)=94.79(11)$.

The spectroscopic data of $\mathbf{3}$ and $\mathbf{4}$ are consistent with the solid-state structure. The $v(\mathrm{CO})$ spectra of $\mathbf{3}$ and $\mathbf{4}$ are super-imposable and each contains four intense bands in the 2024$1911 \mathrm{~cm}^{-1}$ region, indicating that all the carbonyl groups are terminal. The ${ }^{1} \mathrm{H}$ NMR spectrum of 3 exhibits seven well-separated resonances (six integrating 1:1, one with a 2:1) in the aromatic region ( $\delta$ 8.64-7.29) due to three non-equivalent thiazole rings (two intact and one $\mathrm{C}-\mathrm{H}$ activated). This is further substantiated by the presence of a singlet in the high field region at $\delta-8.66$ which must be attributed to the bridging hydride ligand. The ${ }^{1} \mathrm{H}$ NMR spectrum of 4 shows five equal intensity singlets in the aromatic region ( $\delta 8.77-6.86)$, each integrating for one proton and three singlets in the aliphatic region at $\delta 2.82,2.80$ and 2.51 each integrating for thee protons and a high field singlet at $\delta-8.50$ integrating for one proton, consistent with the presence of two intact and one activated 4-methylthiazole ligands. The mass spectra of compounds $\mathbf{3}$ and $\mathbf{4}$ exhibit molecular ion peaks at $\mathrm{m} / \mathrm{z} 795$ and 837 , respectively, which fully agree with the formulae of the compounds, with ion peaks corresponding to six $\mathrm{CO}$ losses being present. 
On heating compound 1 and 5 equiv. of thiazole in the presence of $\mathrm{Me}_{3} \mathrm{NO}$ in benzene at $80^{\circ} \mathrm{C}$ resulted in the formation of $\mathbf{3}$ in $45 \%$ yield. A similar treatment of $\mathbf{2}$ with 4-methylthiazole afforded compound $\mathbf{4}$ in $40 \%$ yield. This observation suggests that compounds $\mathbf{3}$ and $\mathbf{4}$ are formed via the intermediate formation of $\mathbf{2}$ and $\mathbf{3}$, respectively.

The molecular structure of $\mathbf{5}$ is shown in Fig. 5 and selected bond distances and angles are listed in caption. The compound contains a single rhenium atom with three carbonyl groups, two $\mathrm{N}$-coordinated $\eta^{1}$-thiazole ligands and a terminally coordinated $\mathrm{Cl}$ ligand. The coordination geometry at the Re atom is a distorted octahedron with three carbonyl ligands arranged in a facial fashion. The distortion from octahedral coordination geometry is evident from reduction of the $\mathrm{N}-\mathrm{Re}-\mathrm{N}$ angles from $90^{\circ}$ in the idealized polyhedron to $84.52(13)^{\circ}$ in $\mathbf{5}$.

The trans angles about rhenium range from $174.44(18)^{\circ}$ to $179.27(19)^{\circ}$ which are comparable to the corresponding angles in $\left[\operatorname{Re}(\mathrm{CO})_{3}\left(\eta^{2}-\mathrm{dpp}\right) \mathrm{Cl}\right]\{\mathrm{dpp}=2,3$-bis(2-pyridyl)pyrazine $\}$ \{range from $171.2(2)^{\circ}$ to $\left.179.4(2)^{\circ}\right\} .^{26}$ The $\mathrm{Re}-\mathrm{Cl}$ bond distance $\{2.4085(17) \AA\}$ is significantly shorter than those observed in $\left[\operatorname{Re}(\mathrm{CO})_{3}\left(\eta^{2}-\mathrm{dpp}\right) \mathrm{Cl}\right]\{2.476(2) \AA\}^{26}$ and $\left[\operatorname{Re}(\mathrm{CO})_{3}\left(\eta^{2}-\mathrm{dppt}\right) \mathrm{Cl}\right]$ $\left\{\right.$ dppt $=5$,6-diphenyl-3-(2-pyridyl-1,2-trazine) $\left\{\right.$ 2.4809(18) Å\}. ${ }^{27}$ The Re-N bond distances $\{\operatorname{Re}(1)-\mathrm{N}(1)=2.185(6), \operatorname{Re}(1)-\mathrm{N}(1 \mathrm{~A})=2.210(6) \AA\}$ are comparable to the Re-N bond distances in $\left[\operatorname{Re}(\mathrm{CO})_{3}\left(\eta^{2}-\mathrm{dpp}\right) \mathrm{Cl}\right]\{1.178(5)-2.175(5) \AA\} .{ }^{26}$ The carbonyl groups assume a fac geometry with an average Re-CO bond distance of 1.914(7) similar to the average Re-CO bond distances in $\left[\operatorname{Re}(\mathrm{CO})_{3}\left(\eta^{2}-\mathrm{dpp}\right) \mathrm{Cl}\right]\{1.915(7) \AA\}{ }^{26}$

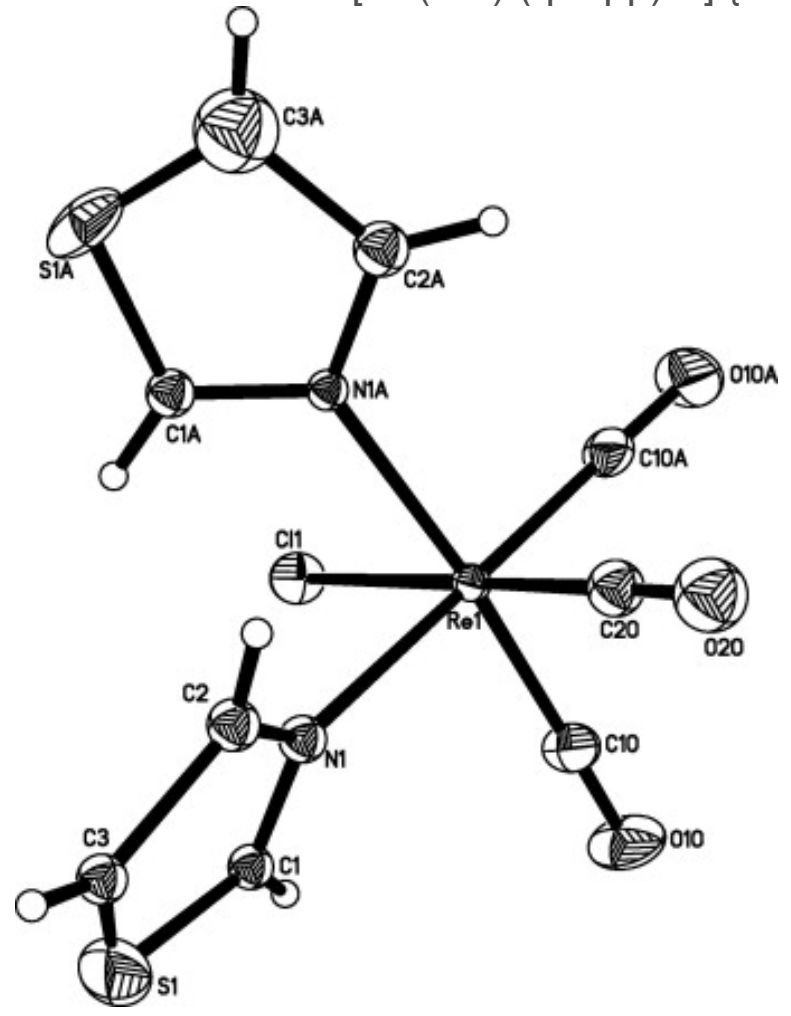

Fig. 5. Molecular structure of complex fac- $\left[\operatorname{Re}(\mathrm{CO})_{3}(\mathrm{Cl})\left(\mathrm{\eta}^{1}-\mathrm{NC}_{3} \mathrm{H}_{3} \mathrm{~S}\right)_{2}\right](5)$. Selected bond lengths $(\AA)$ and angles $\left({ }^{\circ}\right): \operatorname{Re}(1)-C(10 A)=1.914(2), \operatorname{Re}(1)-C(10)=1.914(2), \operatorname{Re}(1)-C(20)=1.915(8), \operatorname{Re}(1)-$ 
$\mathrm{N}(1)=2.185(6), \operatorname{Re}(1)-\mathrm{N}(1 \mathrm{~A})=2.210(6), \operatorname{Re}(1)-\mathrm{Cl}(1)=2.4085(17), \mathrm{N}(1)-\operatorname{Re}(1)-\mathrm{N}(1 \mathrm{~A})=5.1(3), \mathrm{N}(1)-$ $\mathrm{Re}(1)-\mathrm{Cl}(1)=85.84(18), \mathrm{N}(1 \mathrm{~A})-\mathrm{Re}(1)-\mathrm{Cl}(1)=90.29(16), \mathrm{C}(10)-\mathrm{Re}(1)-\mathrm{Cl}(1)=90.06(9), \mathrm{C}(10)-\operatorname{Re}(1)-$ $\mathrm{N}(1)=92.3(2), \mathrm{N}(1)-\mathrm{Re}(1)-\mathrm{N}(1 \mathrm{~A})=86.9(4), \mathrm{C}(10)-\mathrm{Re}(1)-\mathrm{N}(1 \mathrm{~A})=179.27(19), \mathrm{C}(10 \mathrm{~A})-\operatorname{Re}(1)-$ $N(1 A)=174.44(18), C(10)-\operatorname{Re}(1)-N(1 A)=174.44(18)$.

The spectroscopic data of $\mathbf{5}$ are consistent with the solid-state structure and the spectroscopic data of $\mathbf{6}$ are consistent with the structure proposed in Scheme 1. The infrared spectra of the complexes (2028 vs, 1924 s, 1889 s cm$^{-1}$ for 5; 2028 vs, 1923 s, 1887 s cm$^{-1}$ for 6) display three bands in the carbonyl stretching region: a shrap intense band at $2028 \mathrm{~cm}^{-1}$ and two lower energy bands closely spaced (1924-1887 $\left.\mathrm{cm}^{-1}\right)$, similar to those observed for $\left[\operatorname{Re}(\mathrm{CO})_{3}(\right.$ tpy $\left.) \mathrm{Cl}\right],{ }^{28}\left[\operatorname{Re}(\mathrm{CO})_{3}(\right.$ ph-tpy $\left.) \mathrm{Br}\right],{ }^{29}\left[\operatorname{Re}(\mathrm{CO})_{3}(\text { diimine }) \mathrm{Cl}\right]^{30}$ and $\left[\operatorname{Re}(\mathrm{CO})_{3}(\mathrm{dpop}) \mathrm{Cl}\right]^{31}$ (dpop = dipyrido(2,3-a:3,2-j)phenazene), which indicate the fac arrangement of the carbonyls. The ${ }^{1} \mathrm{H}$ NMR spectrum of 5 shows a singlet at $\delta 9.38$ due the proton attached to $\mathrm{C}(2)$ atom and two doublets at $\delta 8.11$ and $7.47(\mathrm{~J}=3.2 \mathrm{~Hz})$ assigned to the protons attached to $\mathrm{C}(4)$ and $\mathrm{C}(5)$ atoms interchangeably. As expected the aromatic region of the ${ }^{1} \mathrm{H}$ NMR spectrum of 6 shows two singlets at $\delta 8.63$ and 7.91 due to the protons attached to $C(2)$ and $C(5)$ atoms interchangeably and the aliphatic region exhibits a singlet $\delta 2.79$ due to the methyl protons of the ligands. The mass spectra of $\mathbf{5}$ and $\mathbf{6}$ exhibit molecular ion peaks at $\mathrm{m} / \mathrm{z} 476$ and 504, respectively, corresponding to their formulation and ions due to the successive loss of thee carbonyl groups. Formation of compounds $\mathbf{5}$ and $\mathbf{6}$ is believed to proceed via the intermediate formation of dirhenium compounds of the type $\left[\mathrm{fn}^{1-} \mathrm{NC}_{3} \mathrm{H}_{2}(4-\right.$ $\left.\mathrm{R}) \mathrm{S}\}_{2}(\mathrm{OC})_{3} \mathrm{Re}-\mathrm{Re}(\mathrm{CO})_{3}\left\{\eta^{1}-\mathrm{NC}_{3} \mathrm{H}_{2}(4-\mathrm{R}) \mathrm{S}\right\}_{2}\right]$, which undergo Re-Re bond cleavage forming the extremely unstable species, $\left[\operatorname{Re}(\mathrm{CO})_{3}\left\{\eta^{1}-\mathrm{NC}_{3} \mathrm{H}_{2}(4-\mathrm{R}) \mathrm{S}\right\}_{2}\right]$ either during the process of work up or recrystallization. This species then combines with chloride of $\mathrm{CH}_{2} \mathrm{Cl}_{2}$, however, this has not been confirmed.

\section{CONCLUSIONS}

The reactions of the labile complex $\left[\operatorname{Re}_{2}(\mathrm{CO})_{8}(\mathrm{MeCN})_{2}\right]$ with thiazole and 4-methylthiazole have been investigated. Four new rhenium carbonyl complexes bearing terminal thiazole and bridging thiazolide ligands (1-4) derived from reactions of thiazole and 4-methylthiazole with $\left[\mathrm{Re}_{2}(\mathrm{CO})_{8}(\mathrm{MeCN})_{2}\right]$ have been structurally characterized. Compounds 1-4 have interesting structures due to having the heterocyclic ligands in both bridging and terminal coordination modes in one molecule. An individual example of both $\eta^{1}$ and bridging $\mathrm{N}$-coordinating aromatic heterocyclic ligands is known but to our knowledge compounds 1-4represent new examples of dirhenium compounds bearing $\mathrm{N}$ and $\mathrm{S}$ containing heterocylic ligands in different coordination modes. Possible route for the formation of complexes $\mathbf{1}$ and $\mathbf{2}$ may be envisaged. It is proposed that $\left[\mathrm{Re}_{2}(\mathrm{CO})_{8}(\mathrm{MeCN})_{2}\right]$ dissociates into coordinatively unsaturated species $\left[\operatorname{Re}_{2}(\mathrm{CO})_{8}(\mathrm{MeCN})\right]$. Thiazole coordinates via a $\sigma-\mathrm{N}$ bond to form $\eta^{1-}\left[\operatorname{Re}_{2}(\mathrm{CO})_{8}(\mathrm{MeCN})\left(\eta^{1-}\right.\right.$ 
thiazole)] which then further dissociates and a second thiazole moiety becomes coordinated to form $\left[\operatorname{Re}_{2}(\mathrm{CO})_{7}(\mathrm{MeCN})\left(\eta^{1} \text {-thiazole }\right)_{2}\right]$. Compounds $\mathbf{1}$ and $\mathbf{2}$ may then be formed via $\mathrm{C}-\mathrm{H}$ oxidative addition of one of the thiazole ligands followed by subsequent dissociation of the $\mathrm{MeCN}$ ligand. Compounds $\mathbf{3}$ and $\mathbf{4}$ are then formed from 1and $\mathbf{2}$ by a further $\mathrm{CO}$ dissociation followed by coordination of a third molecule of thiazole via the nitrogen atom. We have demonstrated this by reacting both $\mathbf{1}$ and $\mathbf{2}$ with thiazole and 4-methylthiazole in the presence of $\mathrm{Me}_{3} \mathrm{NO}$ in refluxing benzene leading to the formation of 3and 4, respectively.

\section{SUPPLEMENTARY MATERIAL}

CCDC 652009, 648040, 607490, 607487 and 607486 contain the supplementary crystallographic data for 1, 2, 3, 4 and 5 . These data can be obtained free of charge via http://www.ccdc.cam.ac.uk/conts/retrieving.html, or from the Cambridge Crystallographic Data Centre, 12 Union Road, Cambridge CB2 1EZ, UK; fax: (+44) 1223-336-033; or email: deposit@ccdc.cam.ac.uk.

\section{ACKNOWLEDGEMENT}

One of us (FA) gratefully acknowledges the University Grants Commission of Bangladesh for a Scholarship.

\section{REFERENCES}

${ }^{1}$ (a) R.A. Machado, M.C. Goite, D. Rivillo, Y. De Sanctis, A.J. Arce, A.J. Deeming, L. D'Ornelas, A.Sierralta, R. Atencio, T. Gonzalez, E. Galarza. J. Organomet. Chem., 692 (2007), p. 894 (b) R.A. Machado, D. Rivillo, A.J. Arce, L. D'Ornelas, Y. De Sanctis, R. Atencio, T. Gonzalez, E. Galarza. J. Organomet. Chem., 689 (2004), p. 2486 (c) J. Reedjik.

G. Wilkinson, R.D. Gillard, J.A. McClaverty (Eds.), Comprehensive Coordination Chemistry, vol. 2, Pergamon Press, Oxford (1987), p. 73. (d)

M.A. Reynolds, I.A. Guzei, R.J. Angelici. Organometallics, 20 (2001), p. 1071 (e)

M.A. Reynolds, I.A. Guzei, R.J. Angelici. Chem. Commun. (2001), p. 513 (f)

R.J. Angelici. Polyhedron, 16 (1997), p. 3073 (g)

M.A. Ruben, D. Rivillo, A.J. Arce, Y. De

Sanctis, A.J. Deeming, L. D'Ornelas, D.A. Oliveros. J. Organomet. Chem., 690 (2005), p. 622

${ }^{2}$ (a) J.D. Peterson, W.R. Murphy, R. Sahai, K.J. Brewer, R.R. Rumenski. Coord. Chem. Rev., 261 (1985), p. 64 (b) C. Jiang, T.S.A. Hor, Y.K. Yan, W. Henderson, L.J. McCaffrey. J. Chem. Soc., Dalton Trans. (2000), p. 3204 
${ }^{3}$ (a) H.-J. Haupt, P. Balsaa, U. Florke. Z. Anorg. Allg. Chem., 548 (1987), p. 151 (b) H.-

J. Haupt, O. Krampe, U. Florke. Z. Anorg. Allg. Chem., 622 (1996), p. 807

4J. Grobe, W. Mohr. J. Fluorine Chem., 8 (1976), p. 145. R.D. Adams, J.D. Kuhns.

Polyhedron, 7 (1988), p. 2543. G. Ciani, G. D’Alfonso, P. Romoti, A. Sironi, M. Freni. Inorg. Chem., 22 (1983), p. 3115

5(a) P.O. Nubel, S.R. Wilson, T.L. Brown. Organometallics, 2 (1983), p. 515.

D.R. Gard, T.L. Brown. Organometallics, 1 (1982), p. 1143

${ }^{6}$ S. Top, M. Gunn, G. Jaoen, J. Vaissermann, J.-C. Daran, J.R. Thornback. J. Organomet.

Chem., 414 (1991), p. C22

${ }^{7}$ P.O. Nubel, T.L. Brown. J. Am. Chem. Soc., 106 (1984), p. 644

${ }^{8}$ C.G. Kreiter, K.-H. Franzreb, W.S. Sheldrick. J. Organomet. Chem., 270 (1984), p. 71

${ }^{9}$ H. Egold, D. Schwarze, U. Flörke. J. Chem. Soc., Dalton Trans. (1999), p. 3203

${ }^{10}$ (a) Y.K. Au, K.K. Cheung, W.-T. Wong. Inorg. Chim. Acta, 228 (1995), p. 267 (b)

Y.K. Au, K.K. Cheung, W.-T. Wong. J. Chem. Soc., Dalton Trans. (1995), p. 1047 (c)

A.J. Deeming, K.I. Hardcastle, M. Karim. Inorg. Chem., 31 (1991), p. 4792. (d)

A.J. Deeming, N.I. Powell, K.I. Hardcastle, M. Karim. Polyhedron, 9 (1990), p. 623 (e)

A.M. Brodie, H.D. Holden, J. Lewis, M.J. Taylor. J. Chem. Soc., Dalton Trans. (1986),

p. 4792

${ }^{11}$ R. Dilshad, K.M. Hanif, M.B. Hursthouse, S.E. Kabir, K.M.A. Malik, E. Rosenberg. J.

Organomet. Chem., 588 (1999), p. 100

${ }^{12}$ K.M. Hanif, M.B. Hursthouse, S.E. Kabir, K.M.A. Malik, E. Rosenberg. J. Organomet. Chem., 580 (1999), p. 60

${ }^{13}$ K.A. Azam, R. Dilshad, S.E. Kabir, K. Khatoon, L. Nessa, M.M. Rahman, E. Rosenberg, M.B. Hursthouse, K.M.A. Malik, A.J. Deeming. J. Chem. Soc., Dalton Trans. (1996), p. 1731

${ }^{14}$ K.A. Azam, S.A. Hussain, S.E. Kabir, M.M. Rahman, M.B. Hursthouse, K.M.A. Malik, E. Rose nberg. J. Organomet. Chem., 559 (1998), p. 81

${ }^{15}$ K.A. Azam, M.B. Hursthouse, S.E. Kabir, K.M.A. Malik, M. Tesmer, H. Vahrenkamp. Inorg. Chem. Commun., 1 (1998), p. 402

${ }^{16}$ M.I. Bruce, P.J. Jow. J. Organomet. Chem., 519 (1996), p. 221

${ }^{17}$ SAINT software for CCD diffractometer, V.7.23A, Bruker AXS, 2005.

${ }^{18}$ G.M. Sheldrick, SADAB 5, Program for empirical absorption correction of area-detector data, Institüt für Anorganische Chemie der Universität, Göttingen, Germany, 1996.

${ }^{19}$ Program XS from SHELXTL package, V. 6.12, Bruker AXS, 2001.

${ }^{20}$ Program XL from SHELXTL package, V. 6.10, Bruker AXS, 2001.

${ }^{21}$ Z. Otwinowski, W. Minor. C.W. Carter Jr., R.M. Sweet (Eds.), Macromolecular

Crystallography, Academic Press, New York (1997), pp. 307-326

${ }^{22}$ R.H. Blessing. Acta Crystallogr., A51 (1995), p. 33

${ }^{23}$ R.H. Blessing. J. Appl. Crystallogr., 30 (1997), p. 421

${ }^{24}$ G.M. Sheldrick. Acta Crystallogr. Sect., A, 46 (1990), p. 467

${ }^{25}$ M.R. Churchill, K.N. Amoh, H. Wasserman. J. Inorg. Chem., 20 (1981), p. 1609

${ }^{26}$ J.R. Kirchhoff, K.K. Kirschbaum. Polyhedron, 17 (1998), p. 4033 
${ }^{27}$ B. Machura, R. Kruszynski, J. Kusz. Polyhedron, 26 (2007), p. 1590

${ }^{28}$ E.W. Abel, V.S. Dimitrov, N.J. Long, K.G. Orrell, A.G. Osbrone, H.M. Pain, V. Sik, M.B. Hurst house, M.A.Mazid. J. Chem. Soc., Dalton Trans. (1993), p. 597

${ }^{29}$ S.A. Moya, R. Pastene, H. Le Bozec, P.J. Baricelli, A.J. Pardey, J. Gimeno. Inorg. Chim. Acta, 312 (2001), p. 7

${ }^{30}$ P.J. Giordano, M.S. Wrighton. J. Am. Chem. Soc., 101 (1979), p. 2888

${ }^{31}$ K.D. Zimmer, R. Shoemaker, R.R. Ruminski. Inorg. Chim. Acta, 359 (2006), p. 1478 